\title{
THE IMPACT OF LARGE TAX SETTLEMENTS ON FIRMS' SUBSEQUENT TAX
} AND FINANCIAL REPORTING

$$
\text { by }
$$

Andrew Rhodes Finley

A Dissertation Submitted to the Faculty of the

\section{DEPARTMENT OF ACCOUNTING}

In Partial Fulfillment of the Requirements

For the Degree of

DOCTOR OF PHILOSOPHY

In the Graduate College

THE UNIVERSITY OF ARIZONA

2015 


\section{THE UNIVERSITY OF ARIZONA GRADUATE COLLEGE}

As members of the Dissertation Committee, we certify that we have read the dissertation prepared by Andrew Rhodes Finley, titled The Impact of Large Tax Settlements on Firms' Subsequent Tax and Financial Reporting and recommend that it be accepted as fulfilling the dissertation requirement for the Degree of Doctor of Philosophy.

Date: $(3 / 27 / 2015)$

Dan S. Dhaliwal

Date: $(3 / 27 / 2015)$

Shyam S. Vallabhajosyula

Date: $(3 / 27 / 2015)$

Katharine D. Drake

Final approval and acceptance of this dissertation is contingent upon the candidate's submission of the final copies of the dissertation to the Graduate College.

I hereby certify that I have read this dissertation prepared under my direction and recommend that it be accepted as fulfilling the dissertation requirement.

Date: $(3 / 27 / 2015)$

Dissertation Director: Dan S. Dhaliwal 


\section{STATEMENT BY AUTHOR}

This dissertation has been submitted in partial fulfillment of the requirements for an advanced degree at the University of Arizona and is deposited in the University Library to be made available to borrowers under rules of the Library.

Brief quotations from this dissertation are allowable without special permission, provided that an accurate acknowledgement of the source is made. Requests for permission for extended quotation from or reproduction of this manuscript in whole or in part may be granted by the head of the major department or the Dean of the Graduate College when in his or her judgment the proposed use of the material is in the interests of scholarship. In all other instances, however, permission must be obtained from the author.

SIGNED: Andrew Rhodes Finley 


\section{ACKNOWLEDGMENTS}

I would like to thank my dissertation committee members: Dan Dhaliwal (chair), Shyam Sunder, and Katharine Drake for their valuable comments and support. I am also thankful to Lin Cheng, Eric Kelley, Allison Koester, Brigitte Muehlmann, Leslie Robinson, Jim Stekelberg, Luke Watson, Laura Wellman, workshop participants at Claremont McKenna College, Loyola Marymount University, and the University of Arizona, participants at the 2015 American Tax Association Mid-Year meeting, the 2014 Deloitte Doctoral Consortium, the University of Arizona tax readings group, and the University of Texas tax readings group. I am thankful to the Accounting Doctoral Scholars Program for financial support. 


\section{TABLE OF CONTENTS}

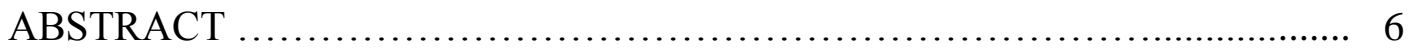

1. INTRODUCTION .............................................................. 7

2. INSTITUTIONAL BACKGROUND .................................... 14

3. PRIOR LITERATURE AND HYPOTHESES DEVELOPMENT ............ 17

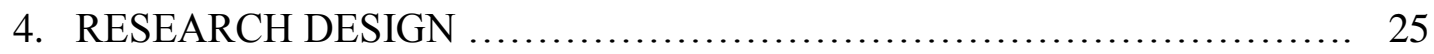

4.1 LARGE SETTLEMENT FIRMS ….......................... 25

4.2 DESIGN SPECIFICATIONS _................................. 29

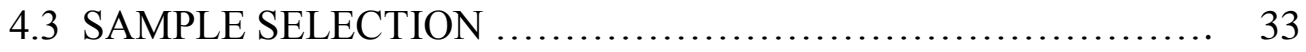

5. RESULTS ….............................................................. 35

5.1 DESCRIPTIVE STATISTICS ................................. 35

5.2 MULTIVARIATE RESULTS .................................. 36

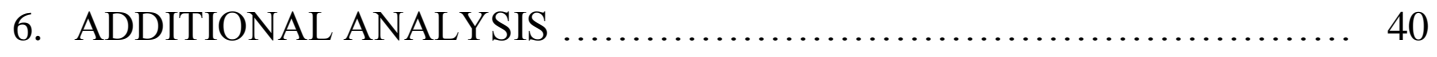

6.1 COMPARISON OF ADEQUATELY RESERVED AND

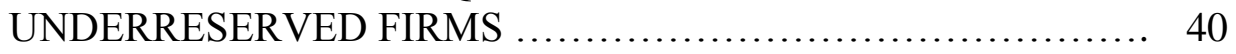

6.2 ROBUSTNESS OF LARGE SETTLEMENT FIRM

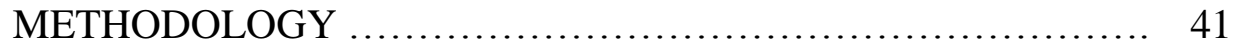

6.3 ROBUSTNESS OF CHANGES IN FINANCIAL REPORTING ..... 44

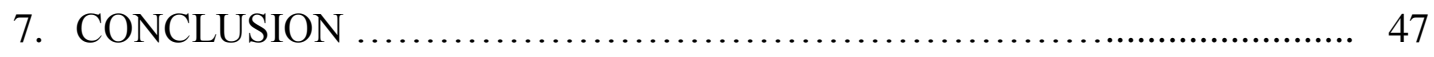

APPENDIX A: VARIABLE DEFINITIONS ............................. 49

APPENDIX B: FIN 48 TABULAR ROLLFORWARD ...................... 50

APPENDIX C: PROPENSITY-SCORE MATCHING ANALYSIS ............ 51

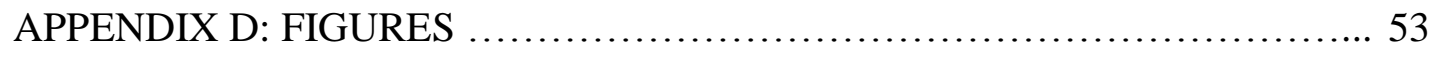

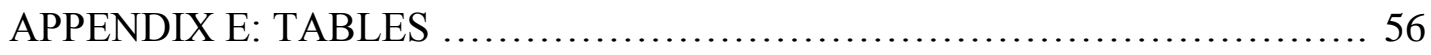

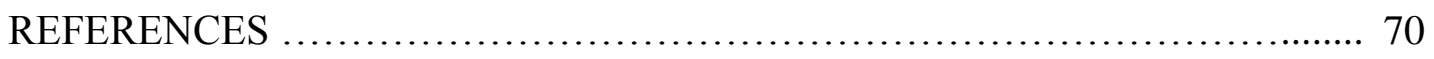




\begin{abstract}
In this study, I examine how firms change their tax avoidance and financial reporting following large tax settlements. I find that firms decrease tax avoidance following large settlements and this effect is concentrated among firms under-reserved for the settlement for financial accounting purposes. Additionally, my results suggest firms learn from tax examination resolutions in a way that affects their financial reporting over the tax account. Finally, I find that the effect of large settlements also spills over to firms within the same auditor network. This study provides context to the tax authority's efficacy in deterring tax avoidance and highlights its role in the financial reporting process.
\end{abstract}




\section{INTRODUCTION}

This study examines how large settlements with the tax authority affect subsequent tax avoidance and financial reporting choices. Specifically, I test how firms change their tax avoidance behavior and financial statement accruals for unrecognized tax benefits (UTBs) following a large settlement with the tax authority. As part of this analysis, I consider whether firms that had adequately reserved for the large settlement for financial accounting purposes respond differently to the enforcement outcome than those that did not. Finally, I examine whether the effect of large settlements on tax avoidance spills over to firms within the same auditor network.

Given the economic magnitude of tax avoidance and governments' limited ability to comprehensively monitor firm behavior, it is important to understand how firms respond to settlements with the tax authority. For instance, the Internal Revenue Service (IRS) recently estimated the corporate tax gap in 2006 more than doubled since 2001 to $\$ 67$ billion, which represents almost 19 percent of corporate taxes collected (IRS 2012a; OMB 2014). To the extent that actions taken by the tax authority affect the tax gap, this in turn impacts governments' ability to generate revenue to fund services. By examining firm responses following large settlements, this study provides new evidence on the tax authority's efficacy in deterring tax avoidance.

To date, extant literature documenting the effect of settlements on subsequent tax avoidance has been limited to laboratory tests and field studies of individual tax returns (i.e., Alm and McKee 2006; Erard 1992; Gemmell and Ratto 2012). Studying corporate responses to tax enforcement provides unique insights relative to studies that utilize laboratory subjects or focus on individual taxpayers for several reasons. First, although 
laboratory experiments benefit from a controlled environment, there are legitimate concerns about the generalizability of these studies (Alm 2012; Levitt and List 2007) that I overcome in my archival setting. Second, differences in risk tolerances and sense of civic duty between individuals and publicly held corporations could produce varying responses to tax enforcement (Slemrod 2004). Third, publicly held corporations are generally subject to more frequent audits compared to individual taxpayers, which may alter their response to tax enforcement. ${ }^{1}$ Finally, corporations may respond to tax enforcement by modifying the tax benefits they claim on their returns, how they report those benefits for financial statement purposes, or some combination of the two. The financial statement reporting of tax benefits is not available to individual taxpayers and is a response mechanism I exploit in conducting this study.

Following extant literature, I broadly define tax avoidance as the reduction of taxes paid (Dyreng, Hanlon, and Maydew 2008). This definition suggests firms may avoid taxes through tax-motivated transactions (i.e., aggressive sheltering activities) or through their normal course of operations (i.e., research expenditures that may qualify for the R\&D tax credit). Large settlements may occur under either type of tax avoidance. ${ }^{2}$ Although prior literature indicates the ex ante threat of enforcement deters corporate tax avoidance (Hoopes, Mescall, and Pittman 2012; Graham, Hanlon, Shevlin, and Shroff 2014; Ayers, Seidman, and Towery 2014), it is unclear whether the ex post realization of enforcement has the same effect. For instance, DeBacker, Heim, Tran, and Yuskavage (2013) find that firms increase tax avoidance following audits, indicating that

\footnotetext{
${ }^{1}$ In 2012, the IRS examined 93\% of returns filed the previous year among firms with greater than $\$ 20$ billion in total assets. In contrast, the IRS examined $12.1 \%$ of individual returns with reported income greater than \$1 million (IRS 2012b).

${ }^{2}$ For instance, the tax authority may reject particular sheltering techniques or disallow certain research expenditures claimed towards the tax credit.
} 
examinations by themselves are insufficient deterrents to tax avoidance. Further, Saavedra (2014) notes that firms with extremely high annual cash ETRs are more likely to make unusually large tax payments again within the following five years. This implies that even when the tax authority rejects a firm's position in an examination, firms continue to engage in tax avoidance and get caught in subsequent periods, further calling into question the tax authority's efficacy in deterring avoidance. I build on this finding by considering a specific condition that could affect whether firms change their behavior following a large tax settlement.

To conduct my tests, I employ Bauer and Klassen's (2014) methodology in identifying potential large tax settlement firm-years. Specifically, I classify a firm-year with an annual cash effective tax rate (ETR) significantly greater than its ten-year mean (e.g., exceeding two industry standard deviations) as a large settlement firm-year. ${ }^{3}$ In supplemental analysis, I modify this criterion and attempt to validate these observations as large settlements based on disclosures in firms' financial statements. I then compare these firms' cash ETRs in the periods immediately before and after the large settlement. If the tax authority's demonstrated enforcement deters subsequent tax avoidance, I expect that firms will have higher cash ETRs (i.e., lower tax avoidance) in the period following a large tax settlement.

Next, I consider whether firms that under-reserved for the settlement for financial accounting purposes decrease their tax avoidance following the enforcement outcome more than adequately reserved firms. I consider firms under-reserved if their current GAAP ETR "current ETR" around the settlement year is significantly greater than their

\footnotetext{
${ }^{3}$ I am not able to directly observe large tax settlements and acknowledge alternate explanations exist for the high cash ETR. In my research design section, I discuss this issue in further detail.
} 
ten-year mean (e.g., exceeding two industry standard deviations). As an example of under-reserving, Pulte Homes, Inc. recognized an additional \$11.8 million tax expense attributable to tax settlements in its 2006 financial statements. This suggests Pulte Homes was either unaware of the weaknesses in its positions or underestimated the tax authority's vigilance. In contrast, GlaxoSmithKline settled a transfer pricing dispute with the Internal Revenue Service (IRS) in 2006 for $\$ 3.4$ billion in what was believed to be one of the biggest tax settlements in US history (Reed 2006). Because the firm had adequately reserved for this settlement for financial accounting purposes, the enforcement outcome did not have a significant impact on the firm's 2006 tax rate or earnings. This suggests GlaxoSmithKline was aware of the possibility its positions would be overturned in an examination.

Because adequately reserved firms already had some awareness of the tax authority's vigilance and sustainability of their positions, they presumably learn less from a large tax settlement relative to under-reserved firms whose expectations of the benefits derived from tax avoidance decrease when their positions are overturned by the tax authority. Consequently, I expect under-reserved firms to decrease their tax avoidance following a large settlement more than adequately reserved firms.

Additionally, I consider the effect of large tax settlements on subsequent financial reporting of unrecognized tax benefits (UTBs). Under FIN 48, firms are required to record reserves for UTBs for financial accounting purposes when the tax positions claimed on a return fail to meet certain thresholds. ${ }^{4}$ Furthermore, the accounting standard

\footnotetext{
${ }^{4}$ FIN 48 was codified as Accounting Standards Codification (ASC) 740-10 as of July 1, 2009. Under this standard, the tax benefit of positions that do not meet the more-likely-than-not "MLTN" recognition threshold are not recognized (i.e., fully reserved) for financial reporting purposes. Furthermore, for positions meeting the MLTN threshold but are not highly certain, firms may only recognize the largest
} 
explicitly states that new information, including interactions with the tax authority, should impact how firms measure and recognize UTBs. ${ }^{5}$ Because large settlements reflect interactions with the tax authority, I expect firms to learn from these events and change their subsequent UTB reporting. The expected direction of such a change, however, is unclear. Large settlements may encourage more conservative financial reporting that results in greater increases in subsequently reserved UTBs. Alternatively, large settlements may produce clarity surrounding a firm's tax positions that result in fewer increases in subsequently reserved UTBs.

Finally, I test whether non-settlement firms that engage the same auditor-office as a large-settlement firm change their tax avoidance following the large-settlement firm's enforcement outcome. In a laboratory setting, Alm, Jackson, and McKee (2009) find that subjects informally revealing their tax examination history affect other subjects' tax avoidance decisions. External auditors provide an important communication mechanism through which their clients can potentially learn about the tax authority's enforcement efforts. By observing a large settlement at one client, external auditors can inform their other clients of the tax authority's vigilance, which may affect the other clients' tax avoidance decisions.

I find that, on average, firms decrease tax avoidance following large settlements. This response is concentrated among under-reserved firms where the large settlement provides them with new information that triggers a behavioral change. Adequately reserved firms, on the other hand, show very little evidence of changing their tax avoidance following large settlements. I note that under-reserved firms are more likely to taxing authority (ASC 740-10-25-6 and ASC 740-10-30-7).

${ }^{5}$ See ASC 740-10-55-109 and ASC 740-10-25-7. 
have internal control weaknesses over the tax account and less likely to purchase tax services from their external auditor than adequately reserved firms in the years leading up to the settlement. This suggests information asymmetries preclude them fully understanding the weaknesses in their tax positions and explains why the enforcement outcome is more informative in shaping their future tax avoidance. I also provide evidence that adequately reserved firms decrease their UTB accruals and that underreserved firms increase their UTB accruals relative to adequately reserved firms following a large settlement. This suggests that a large settlement's impact on financial reporting over the tax account varies with firms' financial reporting choices prior to the enforcement outcome. Finally, I find that firms engaging the same external auditor-office as an under-reserved firm also decrease tax avoidance following the under-reserved firm's large settlement. This spillover effect is not present among firms engaging the same external auditor-office as an adequately reserved firm.

This study provides three distinct contributions to the literature. First, it informs governments regarding the efficacy of the tax authority's efforts in deterring tax avoidance. While my evidence indicates large tax settlements deter subsequent avoidance, this effect appears limited to firms that had not adequately reserved for the settlement for financial reporting purposes. This implies firms' ex ante expectations of a large settlement impacts their response to the tax authority's demonstrated enforcement. Second, this study provides evidence to regulators and researchers examining the determinants of firms' UTB reporting under FIN 48. Extant literature suggests significant latitude in firms' reporting over this contingent liability (De Simone, Robinson, and Stomberg 2014). My findings point to the tax authority's role in the financial reporting 
process and suggest firms take recent interactions with the tax authority into account when measuring their reserves under this reporting standard. Finally, my external auditoroffice analysis provides evidence of a mechanism through which the tax authority's efforts can indirectly affect tax avoidance among firms not subject to large settlements. My findings suggest external auditors disseminate information about the tax authority's vigilance and influence the tax avoidance activities of their clients, which ultimately affects revenues generated by the government.

The remainder of this paper proceeds as follows. Section 2 provides institutional background regarding financial statement reporting of the tax account, Section 3 reviews prior literature and develops my hypotheses, Section 4 outlines the research design and sample selection procedure, Section 5 presents results, Section 6 discusses additional analysis, and Section 7 concludes. 


\section{INSTITUTIONAL BACKGROUND}

For fiscal periods beginning after December 15, 2006, FIN 48 requires firms to evaluate each individual tax position taken on any foreign or domestic tax return, including the decision to file a return, and determine whether "it is more-likely-than-not, based on the technical merits, that the [tax] position will be sustained upon examination" (FASB 2006, 5). Importantly, firms must assume the tax authority will examine the position and have full knowledge of all relevant information. FIN 48 requires that firms record a contingent liability equal to the tax liability exposure for those positions that do not meet this threshold in the year the position is taken, such that the economic benefit is not recognized for financial statement purposes. Further, for those positions that meet the more-likely-than-not (MLTN) threshold, firms only recognize "the largest amount of tax benefit that is greater than fifty percent likely of being realized upon effective settlement with the tax authority" (FASB 2006, 5). The standard requires firms to establish reserves, referred to as unrecognized tax benefits (UTBs), for the difference between the economic benefit of the position reported on the tax return and the benefit recognized for financial statement purposes.

As an example, suppose Firm A and B claim $\$ 100$ research and development (R\&D) tax credits on their current year tax returns. When analyzing the expenditures giving rise to the credit, Firm A's management determines there is only a $40 \%$ likelihood that the entire $\$ 100$ will be retained upon settlement in an examination and a $60 \%$ likelihood that at least an $\$ 80$ benefit will be retained. Because $\$ 80$ represents the largest amount of tax benefit that is greater than fifty percent likely of being realized and $\$ 100$ represents the benefit claimed on a tax return, Firm A would record a $\$ 20$ reserve in the 
current year for this tax position under FIN 48. Firm B's management, on the other hand, believes it is highly certain that $\$ 100$ tax benefit will be retained in an examination and consequently does not record any reserve in the current year for its R\&D tax credit position. Furthermore, suppose the tax authority examines both firms' R\&D tax credit positions in a subsequent year and overturns $\$ 20$ of the claimed benefit for both firms. Under this scenario, Firm A will not accrue any additional current tax expense since it had previously reserved for the settlement. Meanwhile, Firm B will accrue an additional $\$ 20$ current tax expense when settling the position in the subsequent year.

Prior to the implementation of FIN 48, firms used a variety of methods to determine the timing and measurement of tax reserves (Blouin and Robinson 2014). SFAS 5, Accounting for Contingencies, discusses loss contingencies related to income tax matters and stipulates reserves should be accrued if the liability is both "probable" and "can be reasonably estimated." (SFAS 5, 8). The discretion afforded under this standard with respect to accruing tax reserves motivated standard setters to implement the more formal guidance found under FIN 48.

Because FIN 48 requires firms to accrue a contingent liability when initially taking the position, a firm's failure to adequately reserve for a large settlement under this regime suggests that management did not expect the tax authority to overturn the firm's tax return positions. The inferences drawn from failing to adequately reserve for large settlements prior to the implementation of FIN 48 are less clear. Although firms record some reserve when taking the position on a tax return, they update this accrual as the audit, appeals, and litigation processes reveal more information (Gleason and Mills 2002). Consequently, failing to adequately reserve for a large tax settlement could reflect 
management's discretion in applying SFAS 5 rather than its expectation of the sustainability of its tax return positions.

Nevertheless, Gleason and Mills (2002) find that reserves for contingent tax liabilities increase with firms' expected losses, suggesting firms with material settlements provisioned for these charges in advance under SFAS 5. Furthermore, the time from when the tax authority first begins examining an issue to the time it reaches a settlement agreement with the firm frequently spans multiple years. ${ }^{6}$ This suggests that firms can anticipate losing a portion of the tax benefit well before formally settling the issue, such that they can accrue a reserve earlier in the examination process once the loss becomes increasingly "probable." Therefore, even under SFAS 5, it is reasonable to proxy for management's expectation of a large tax settlement by identifying whether it had adequately reserved for the enforcement outcome.

\footnotetext{
${ }^{6}$ Gleason and Mills (2002) note that three years generally represents a minimum length to complete an
} audit and propose any adjustments among large firms in the IRS' Coordinated Industry Cases (CIC). 


\section{PRIOR LITERATURE AND HYPOTHESES DEVELOPMENT}

The fundamental question I address is how firms respond to enforcement. For instance, Karpoff, Lee, and Martin (2008) document that firms typically fire managers held culpable of financial misreporting by the Securities Exchange Commission (SEC) or Department of Justice (DOJ). Meanwhile, McNichols and Stubben (2008) find that firms decrease over-investment following SEC investigations, Cheng, Dhaliwal, and Zhang (2013) show that firms improve investment efficiency following the disclosure of internal control weaknesses, and Wiedman and Hendricks (2013) point out that firms improve accrual quality and decrease real earnings management following restatements. Outside the accounting context, Shimshack and Ward (2008) find that non-compliant plants reduce discharges well beyond the required reductions following environmental sanctions. Overall, these studies suggest firms proactively respond to enforcement outcomes to mitigate repeated occurrences in the future.

Extant empirical work identifying responses to tax enforcement outcomes is largely confined to field studies of individual taxpayer returns or laboratory experiments. Individual taxpayer field studies generally confirm the positive impact of the tax authority's vigilance in deterring avoidance (Tauchen, Witte, and Baron 1993; Plumley 1996; Dubin 2007; Gemmell and Ratto 2012). Other studies, however, suggest tax enforcement's deterrent capability is more limited (Long and Schwartz 1987; Erard 1992). Experimentally, Alm and McKee (2006) show that knowledge of the tax authority's productivity impacts reporting decisions, while Alm, Cherry, Jones, and McKee (2010) document that information provided by the tax authority also curtails tax avoidance. 
Evidence documenting the effect of the tax authority's enforcement on corporate tax avoidance is scarce. Although DeBacker et al. (2013) find that firms increase tax avoidance for a few years following a tax examination, their results are not conclusive when considering the outcome of the examination. This is critical to my study that evaluates the effect of large settlements specifically. Hoopes et al. (2012) and Ayers et al. (2014) find that an increased threat of enforcement curtails tax avoidance, while Graham et al.'s (2014) survey of tax executives identifies tax authority scrutiny as an important deterrent to avoidance activities. Meanwhile, extant literature suggests the tax authority pays closer attention to firms whose identifiable proxies for tax avoidance are higher (Mills and Sansing 2000; Bozanic, Hoopes, Thornock, and Williams 2014). If large settlements effectively increase the threat of subsequent scrutiny or decrease firms' expectations of the benefits derived from tax avoidance, I expect firms to decrease tax avoidance following this enforcement outcome.

H1: Firms decrease tax avoidance following large tax settlements.

There are at least three reasons firms may not modify their tax avoidance strategies following large settlements. First, if large settlements pertain to non-recurring transactions, these events would not affect firms' subsequent tax avoidance. Second, if firms are already cognizant of the threat of enforcement, they may strategically choose to maintain their tax avoidance strategies in order to gain "bargaining space" for future negotiations. For example, Slemrod, Blumenthal, and Christian (2001) analyze a controlled experiment in which a group of Minnesota taxpayers received a notice informing them the state would be auditing their return. Among high income individuals, those who received the notice actually decreased their reported tax liability relative to the 
previous year. The authors suggest that increased tax avoidance under stricter monitoring may occur because the positions claimed on the tax return serve as a starting point for negotiations with the tax authority. The implication is that if taxpayers do not claim uncertain benefits on their filed returns, they are conceding these positions to the tax authority before an exam even commences and depriving themselves of valuable bargaining space during the negotiation process.

Third, firms may view the savings from tax avoidance as an external financing mechanism (Edwards, Schwab, and Shevlin 2014). Saavedra (2014) finds that firms with extremely high annual cash-ETRs are more likely to experience another extremely high annual cash-ETR over the following five-year period, suggesting unsuccessful tax avoidance functions similarly to a government loan that is oftentimes repaid. Furthermore, Slemrod (2007) notes that tax authorities oftentimes waive penalties during examinations in order to expedite a settlement, which may incentivize firms to maintain aggressive tax avoidance strategies despite previous enforcement events. If firms reason that the immediate savings from tax avoidance outweigh the expected cost of returning those savings and paying a penalty, then a large settlement would only trigger a change in behavior if it changes the firm's expectations of the overall benefits derived from tax avoidance.

Consistent with this Bayesian framework, Snow and Warren (2007) develop a model showing that individuals update their expectations of future tax audit probability based on past audit experience. The psychology literature similarly demonstrates that when uncertainty makes estimating outcomes difficult, individuals rely on past personal experience to make decisions (Barron and Erev 2003; Hertwig, Barron, Weber, and Erev 
2004). With respect to corporate decision-making, Dittmar and Duchin (2014) find that CEOs' prior personal experiences affect firm capital structure and investment. Furthermore, Malmendier and Nagel (2011) find that "Depression babies" who experienced a large macroeconomic shock during their lifetime are less willing to take on financial risk. These studies suggest managers learn from past experiences in a way that affects their firms' decision-making.

As tax avoidance involves significant uncertainty (Rego and Wilson 2012), Bayesian models predict that information learned through previous interactions with the tax authority affect subsequent managerial decisions to engage in tax avoidance. Specifically, if firms do not expect a large tax settlement, such an outcome informs them of the tax authority's vigilance or the weaknesses of their own positions. Consequently, they will decrease their expectations of the benefits derived from tax avoidance and be less likely to subsequently engage in similar strategies.

One way to gauge if a firm expected a large settlement is to identify whether it had adequately reserved for this event for financial accounting purposes. As financial reporting rules require firms to reserve for tax benefits that may be forfeited to the government prior to a final examination resolution, higher (lower) levels of current tax expense around the settlement year indicate firms had under-reserved (adequately reserved) for the enforcement outcome. I argue that under-reserved firms expect the large tax settlement less than adequately-reserved firms, such that they learn more about the tax authority's vigilance or sustainability of their positions from the enforcement event. ${ }^{7}$

\footnotetext{
${ }^{7}$ To the extent the large settlement adversely impacts under-reserved firms' earnings, this may also provide under-reserved firms with additional incentives to modify their behavior so as to prevent similar financial reporting shocks in the future; however, under-reserved firms could mitigate this financial reporting risk by accruing more reserves prospectively rather than decreasing tax avoidance. Therefore, the information
} 
Consequently, I expect under-reserved firms to decrease tax avoidance relative to adequately reserved firms because their expectations of the benefits derived from tax avoidance decrease following a large tax settlement.

H2: Under-reserved firms decrease tax avoidance following large tax settlements more than adequately reserved firms.

The next part of this study considers how large settlements during the FIN 48 era affect UTB reporting. ASC 740-10-55-109 stipulates that when examination outcomes provide information regarding the technical merits of firms' tax positions, these events should be assessed for future periods, suggesting firms may learn from the resolution and revise their UTB reporting prospectively. It is unclear though, how firms' subsequent UTB reporting might change. On one hand, large settlements may lead to greater increases in subsequent UTBs reported if the enforcement outcome encourages more conservative financial reporting over the tax account, but does not alter tax return reporting. This may occur among firms that value the "bargaining space" created by taking aggressive tax return positions, but modify their financial reporting to account for the expected loss. Alternatively, large settlements may lead to fewer increases in subsequent UTBs reported if the enforcement outcome resolves uncertainty surrounding firms' tax strategies or encourages more conservative tax return reporting. This may hold for both adequately reserved and under-reserved firms. Consequently, I do not offer a directional prediction for the effect of large settlements on subsequent UTB reporting. H3: Firms change their UTB reporting following large tax settlements.

learned through the settlement and its effect on firms' expected benefits derived from tax avoidance provides a more plausible explanation for differential changes in tax avoidance between adequately reserved and under-reserved firms. 
One concern is that if aggressive tax return reporting is associated with aggressive financial reporting, tax aggressive firms may systematically understate their true UTBs. ${ }^{8}$ Robinson, Stomberg, and Towery (2014), however, estimate that for each dollar of UTB reserved, firms pay less than $\$ 0.24$ as a cash settlement over the following two years, suggesting that if anything, firms overstate their true UTBs on average. ${ }^{9}$ Further, Gupta, Laux, and Lynch (2013) do not find any evidence of firms managing earnings through their UTBs post-FIN 48. Finally, Lisowsky, Robinson, and Schmidt (2013) link UTB disclosures to actual tax shelter participation. These aforementioned studies assuage some concerns that firms manipulate UTB reporting and provide credibility to my maintained assumption that firms truthfully accrue their best estimate of current tax expense.

The final part of this study considers whether large tax settlements also affect tax avoidance among firms not subject to the enforcement outcome. In an experimental setting, Alm et al. (2009) find that subjects informally communicate signals about the tax authority's enforcement efforts amongst each other, which results in less tax avoidance when enforcement is more prevalent. In a corporate setting, external auditors can function as intermediaries that disseminate information regarding the tax authority's efforts that affects their clients' tax avoidance. By communicating information regarding the efficacy of tax-planning opportunities among their clientele, auditors can facilitate tax avoidance among their local network firms (Bianchi, Falsetta, Minutti-Meza, and Weisbrod 2014; Brown and Drake 2014). Similarly, when the tax authority rejects a firm's tax positions, as evidenced in large settlement situations, auditors are able to disseminate the

\footnotetext{
${ }^{8}$ For instance, Frank, Lynch, and Rego (2009) find a positive association between aggressive tax and financial reporting.

${ }^{9}$ Drake, Finley, and Koester (2014) similarly find that for every dollar of UTBs resolved in a tax examination, only $\$ 0.23$ is paid out to the tax authority.
} 
enforcement outcome within their network of clients. Kedia and Rajgopal (2011) highlight the importance of local information dissemination in an SEC context. They find that geographic proximity to an SEC office and the agency's past enforcement actions against firms in a particular county deter misreporting among neighboring firms.

In order for large settlements to decrease tax avoidance across an auditor's clientnetwork, the auditor must learn something new from the settlement about the sustainability of a particular tax position and then convey that information to previously unaware clientele. Lennox and $\mathrm{Li}$ (2014) find that accounting misstatements occur less frequently for auditors, specifically at the office-level, after they are subject to recent litigation. The authors suggest this occurs because lawsuits enable auditors to learn of previously unknown deficiencies in their work and embolden them to change their behavior to prevent future litigation.

In my setting, when auditors learn of deficiencies in one client's tax positions, they may subsequently encourage their other clients to decrease tax avoidance to avoid tax authority scrutiny. Auditors who provide tax services may also recommend lower levels of tax avoidance following one client's settlement to protect their own reputation, which could be damaged if the positions they advocate are rejected by the tax authority. I expect this decrease in tax avoidance to occur primarily when the settling client had not adequately reserved for the enforcement outcome, which to some extent suggests the auditor failed to understand the tax authority's vigilance or the sustainability of its client's positions. In such instances, the large settlements may revise auditors' expectations of their other clients' benefits derived from tax avoidance. Communicating these revised expectations among their client network may affect these other firms' tax 
avoidance behavior. Because I do not expect auditors to learn uniformly from tax settlements, I make separate predictions depending upon whether the settling client had adequately reserved for the enforcement outcome.

H4a: When a firm under-reserves for a large tax settlement, other clientele of that firm's auditor-office decrease their tax avoidance.

$H 4 b$ : When a firm adequately reserves for a large tax settlement, other clientele of that firm's auditor-office do not change their tax avoidance. 


\section{RESEARCH DESIGN}

\subsection{Large Settlement Firms}

To test the effect of large tax settlements on subsequent tax avoidance, I must first identify a sample of firms with large tax settlements. I do this following the methodology employed by Bauer and Klassen (2014). The authors identify potential tax loss events as observations in which a firm's cash ETR, defined as taxes paid divided by pre-tax income less special items, exceeds its own ten-year mean by more than two industry standard deviations. I begin with 78,382 observations during 2002-2011 with identifiable SIC codes and non-missing assets in Compustat. ${ }^{10}$ I follow the authors' requirements that sample firms have ten consecutive years of ROA percentages that are greater than or equal to 0.5 percent and that the cash ETR is calculable. ${ }^{11}$ This ensures that the sample is not hindered by small denominator issues or firms with losses. Because I am interested in whether firms had adequately reserved for large settlements, I also require the current ETR, defined as current tax expense divided by pre-tax income less special items, to be calculable. Requiring observations with ten consecutive years of data to calculate the standard deviation of the cash and current ETR reduces my sample to 11,430 observations. Finally, eliminating firms in the banking and regulated industries, consistent with other studies in the tax avoidance arena, reduces my sample to 8,675 observations. I calculate the firm-specific mean and standard deviation of the annual cash ETR over a ten-year window and use firms' standard deviations to calculate the rolling

\footnotetext{
${ }^{10}$ I use 2002 as a starting point, similar to Bauer and Klassen (2014), since the methodology requires 10 prior-years of data and 1993 marked the introduction of SFAS 109, Accounting for Income Taxes, as well as an increase in the top statutory rate from $34 \%$ to $35 \%$ for US federal taxes.

${ }^{11}$ I follow Bauer and Klassen (2014) in truncating the distribution of annual cash ETRs to between zero and one. Further, I define ROA as pretax income less special items divided by total assets so that the numerator is consistent with the cash ETR denominator. Bauer and Klassen (2014) define ROA as pretax income less extraordinary items divided by lag assets.
} 
ten-year industry average standard deviation for each industry-year. ${ }^{12}$ Of this sample, 462 have cash ETRs that exceed their own ten-year average by more than two standard deviations of their industry. Panel A of Table 1 presents the procedure I undertake to identify large settlement firm-years.

To determine whether large-settlement firms had adequately reserved for the enforcement outcome, I evaluate their current ETR around the settlement year. Specifically, I calculate the firm-specific mean and standard deviation of the annual current ETR over the ten-year window and use firms' standard deviations to calculate the rolling ten-year industry average standard deviation for each industry-year. I consider firms under-reserved if their current ETR in the year of or year before settlement exceed their own ten-year average by more than two standard deviations of their industry. ${ }^{13}$ This implies that adequately reserved firms will have relatively stable current ETRs around the settlement year, whereas under-reserved firms will have spikes in their current ETR that mirror the spike in their cash ETR.

Panel B of Table 1 presents the frequency of adequately reserved and underreserved large settlement firm-years by year. Of the 462 large settlement firm-years, 247 are adequately reserved and 215 are under-reserved. Panel $\mathrm{C}$ of Table 1 presents the frequency of large settlements by industry, partitioned by adequately reserved and underreserved firm. The most settlements observed in any given industry in my sample is 43

\footnotetext{
${ }^{12}$ Bauer and Klassen (2014) define industry based on four-digit NAICS industry codes. I define industry at the four-digit SIC level because I delete observations in the banking and regulated industries based on their SIC codes (6000-6999 and 4900-4999, respectively), consistent with the tax avoidance literature.

${ }^{13}$ I truncate the distribution of current ETRs between zero and one. I consider the current ETR in the year prior to settlement in determining whether a firm is under-reserved because firms often agree to tax settlements a year before making the payment. For instance, Merck agreed to settle a large tax dispute in 2006 and made the payment in February 2007 (Merck 2006 Annual Report). In such instances, an underreserved firm would accrue any additional tax expense when they reach the agreement rather than when they make the payment.
} 
('Business Services') and this represents just $4.88 \%$ of that industry's observations with sufficient data. This lack of industry clustering provides support that my analysis is not driven by industry-wide changes in behavior after the authority rejects a specific tax strategy employed by similar types of firms.

Panel D of Table 1 compares descriptive statistics of large settlement and nonsettlement firms. Among firm-years with large settlements, the table also compares adequately reserved and under-reserved firms. By construction, large settlement firms have higher cash-ETRs than non-settlement firms. ${ }^{14}$ It also appears that other fundamental differences exist between large settlement and non-settlement firms. For instance, large settlement firms are smaller, have lower ROA, and have less foreign income. To ensure that my classification of large settlement firms is not a function of these firms' other characteristics, I employ a propensity-score matching (PSM) technique in sensitivity tests that matches large settlement firm-years with non-settlement firmyears based on their observable characteristics.

A limitation of this study is that I am not able to directly observe large tax settlements. Unusual spikes in a firm's one-year cash ETR may occur for reasons other than large tax settlements, including repatriation of foreign earnings, changes in the business, or differences between the tax code and GAAP regarding income recognition. In supplemental analysis, I attempt to validate that the firm-years obtained through this selection procedure represent large settlements; however, this is difficult because

\footnotetext{
${ }^{14}$ The table also suggests that under-reserved firms have larger settlements (i.e., higher cash ETRs) than adequately reserved firms. To alleviate concerns that the magnitude of the settlement drives under-reserved firms' change in tax avoidance, I remove the lowest quartile of large settlements among adequately reserved firms from my sample as a robustness test so that there is no difference in the settlement magnitude between adequately reserved and under-reserved firms. The inferences I draw from my tax avoidance test remain the same under this modification.
} 
adequately reserved firms do not have to disclose settlement information if it does not have a material impact on earnings. Prior research indicates firms rarely provide detailed disclosures about their tax planning and outcomes (Gleason and Mills 2002; Saavedra 2014). Furthermore, even if a firm is under-reserved for a tax settlement, the event may not impact earnings when the settled positions relate to temporary book-tax differences that will reverse in subsequent periods.

To address concerns that fundamental changes in the firm's business, as opposed to large settlements, drive changes in tax reporting, I compare the frequency in which large settlement and non-settlement firms report acquisition or restructuring charges (Compustat variables AQC and RCA). In untabulated analysis, I find that largesettlement firms are not any more likely to incur these expenditures on average than nonsettlement firms. Furthermore, because I remove the effect of special items from the denominator in computing a firm's cash ETR, consistent with Dyreng et al. (2008), it is unlikely my methodology inappropriately classifies large settlement firms because of non-recurring items such as goodwill impairment charges.

To address concerns that my methodology captures favorable (from the firm's perspective) book-tax differences that reverse in year $t$, I compare the deferred tax expense in year $t$ between adequately and under-reserved firms. The reversal of favorable book-tax differences results in higher cash tax payments and current tax expense that could explain the spike in cash and current ETR, but also results in lower deferred tax expense. Since only under-reserved firms have appreciably higher current tax expense in year $t$, I would expect these firms to have appreciably lower deferred tax expense if the event generating the spike in current ETR was the reversal of a temporary book-tax 
difference. However, there is no statistically significant difference in deferred tax expense, scaled by assets or pretax income, between adequately reserved and underreserved firms (untabulated). This suggests my methodology is not inappropriately classifying large settlement firms because of temporary book-tax differences.

With the implementation of FIN 48, firms must disclose decreases in UTBs attributable to tax authority settlements in a tabular rollforward within their annual financial statement (see Appendix B for an example). Additional analysis indicates these settlements, as a function of pretax income less special items, are higher on average for large-settlement relative to non-settlement firms (untabulated). ${ }^{15}$ This provides some assurance that my screening process is capturing firm-years with large tax settlements, though I acknowledge there may be instances in which my selection procedure identifies firm-years that do not have large tax settlements. To the extent this occurs, this should add noise, but not bias, in my tests.

\subsection{Design Specifications}

To test whether firms change their tax avoidance following a large tax settlement, I implement an event study design in which I first compare firms' cash ETR before and after their large settlement. Specifically, I regress a firm's cash ETR on an indicator variable, POST, equal to one for firm-years after the large tax settlement and zero for firm-years beforehand.

CASH_ETR $\mathrm{i}_{\mathrm{i}, \mathrm{t}}=\alpha_{0}+\alpha_{1} * \mathrm{POST}_{\mathrm{i}, \mathrm{t}}+\alpha^{*}$ CONTROLS $_{\mathrm{i}, \mathrm{t}}+\varepsilon_{\mathrm{i}, \mathrm{t}}$

\footnotetext{
${ }^{15}$ As a sensitivity test, I remove all large settlement firm-years that do not disclose settlements with the tax authority in their FIN 48 tabular rollforward. Further, if an under-reserved firm-year's increase in UTBs attributable to prior period positions is smaller than the decrease in UTBs attributable to lapses in the statute of limitations and other decreases in the settlement year and year prior, I re-classify this observation as adequately reserved. I do this because increases in UTBs attributable to prior period positions suggests under-reserving, whereas decreases in UTBs attributable to lapses in the statute of limitations and other decreases suggests over-reserving. The inferences from my results are unchanged by these modifications.
} 
I include control variables, defined in Appendix A, typically found in the tax avoidance literature as well as year and industry fixed effects. ${ }^{16}$ I winsorize all control variables at 1 and 99 percent and truncate cash ETR at 0 and 1, consistent with prior literature (Dyreng et al. 2008; Bauer and Klassen 2014). I expect $\alpha_{1}$ to be positive and significant in the model above if, consistent with Hypothesis 1, firms decrease tax avoidance following large tax settlements.

I use three different specifications in defining my PRE and POST periods. First, I use an annual specification over a three year period, where the PRE period includes firms' annual cash ETRs over years $t-4$ to $t-2$ and the POST period includes firms' annual cash ETRs over years $t+1$ to $t+3$ relative to the settlement year $t$. I exclude year $t-1$ from the PRE period because firms subject to large settlements likely become aware of the enforcement outcome prior to the settlement year and may start to adjust their behavior by this point. Including year $t-1$ in the analysis therefore confounds the ability to accurately capture any response to an enforcement outcome. Second, I use a single year specification, where the PRE period includes firms' cash ETR in year $t-2$ and the POST period includes firms' cash ETR in year $t+1$ relative to the settlement year $t$. Third, I use a single three-year average specification, where the PRE period includes firms' average cash ETR over years $t-4$ to $t-2$ and the POST period includes firms' average cash ETR over years $t+1$ to $t+3$ relative to the settlement year $t$. Figure 1 provides a timeline of my measurement period relative to the settlement year $t$.

There are advantages and disadvantages to each specification. Examining a response over three single-year periods maximizes my sample size and allows me to

\footnotetext{
${ }^{16}$ I use Fama-French 17 industry fixed effects because of limitations in my degrees of freedom that preclude me from using more granular level SIC codes.
} 
evaluate whether the effect of large settlements persists beyond one year. At the same time, prior research suggests significant volatility in annual cash ETRs, such that measuring this variable cumulatively over a longer time window may be more appropriate (Dyreng et al. 2008). Examining a response by comparing year $t-2$ to $t+1$ reduces the likelihood of noise from external events, but still suffers from concerns surrounding the volatility in annual cash ETR measures. Finally, examining a response over a single three-year average period mitigates many of the concerns of the other two specifications, but this approach results in the smallest sample size, thus hindering the power of my tests.

To test Hypothesis 2, I incorporate an indicator variable, UNDERRESERVED, equal to one for firms that did not adequately reserve for the large tax settlement and zero otherwise. I interact this variable with POST to identify the incremental effect that large tax settlements have on under-reserved firms relative to adequately reserved firms.

$\mathrm{CASH}_{2} \mathrm{ETR}_{\mathrm{t}}=\beta_{0}+\beta_{1} * \mathrm{POST}_{\mathrm{i}, \mathrm{t}}+\beta_{2} * \mathrm{UNDERRESERVED}_{\mathrm{i}, \mathrm{t}}+$ $\beta_{3}{ }^{*}$ POST $^{*}$ UNDERRESERVED $_{\mathrm{i}, \mathrm{t}}+\beta * \operatorname{CONTROLS}_{\mathrm{i}, \mathrm{t}}+\varepsilon_{\mathrm{i}, \mathrm{t}}$

I expect $\beta_{3}$ to be positive and significant if, consistent with Hypothesis 2, underreserved firms decrease tax avoidance following large tax settlements incrementally more than adequately reserved firms. An insignificant coefficient on $\beta_{1}$ indicates adequately reserved firms do not change their tax avoidance following enforcement outcomes and suggests that firms already aware of the tax authority's vigilance nevertheless perceive value in maintaining their tax avoidance strategies.

To test my third hypothesis, I use the net current year increases in UTBs for current period positions, scaled by beginning of year assets, as my dependent variable. The current year increases in UTBs for current period positions is disclosed within firms' 
FIN 48 tabular rollforward (see Appendix B for an example). I utilize the same set of controls as my tax avoidance tests. ${ }^{17}$

CYINC_UTB $_{\mathrm{i}, \mathrm{t}}=\lambda_{0}+\lambda_{1} * \mathrm{POST}_{\mathrm{i}, \mathrm{t}}+\lambda * \mathrm{CONTROLS}_{\mathrm{i}, \mathrm{t}}+\varepsilon_{\mathrm{i}, \mathrm{t}}$

Whereas I utilize various time horizons in my tax avoidance tests, I limit the PRE and POST periods to single-years for purposes of this analysis. Specifically, I define the POST period as the year after a large settlement (i.e. year $t+1)$ and the PRE period as the second year before the settlement (i.e. year $t$-2). This is consistent with my single-year specification in the tax avoidance tests. I only utilize an immediate single-year measure for this analysis because there is no evidence that net current year increases for current period UTBs suffer from the volatility concerns that annual cash-ETR measures do.

Because FIN 48 has only been in effect for years beginning after December 15, 2006 and I require UTB information from the PRE and POST periods, my sample for this analysis includes only those large settlements from 2009-2011. This is also another reason I am only able to perform the single-year specification for this analysis. To address my sample size limitations, I employ alternate methodologies to test the effect of large settlements on financial reporting over the tax account. These are discussed in the additional analysis section.

The expected effect of large settlements on subsequent UTB reporting is unclear. If large settlements resolve uncertainty surrounding firms' tax strategies or lead firms to take fewer uncertain tax positions on their tax returns, then I expect $\lambda_{1}$ to be negative and significant. Alternatively, if large settlements lead firms to accrue UTBs more

\footnotetext{
${ }^{17}$ In untabulated analysis, I include cash-ETR as a control variable to provide assurance that the results are capturing financial reporting apart from tax avoidance itself. The inferences on my variables of interest remain unchanged when including cash-ETR as a control. I do not include this variable in my main test, however, because the reduction in sample size due to the requirement that all observations have positive pretax book income less special items further hinders the model's reliability.
} 
conservatively for financial reporting purposes, without necessarily changing their tax return positions, then I expect $\lambda_{1}$ to be positive and significant. Because the effect of large settlements on UTB reporting may differ between adequately reserved and underreserved firms, I include a model that distinguishes these groups of firms.

CYINC_UTB $_{\mathrm{i}, \mathrm{t}}=\gamma_{0}+\gamma_{1} * \mathrm{POST}_{\mathrm{i}, \mathrm{t}}+\gamma_{2} * \mathrm{UNDERRESERVED}_{\mathrm{i}, \mathrm{t}}+$ $\gamma_{3} *$ POST $^{*}$ UNDERRESERVED $_{\mathrm{i}, \mathrm{t}}+\gamma^{*}$ CONTROLS $_{\mathrm{i}, \mathrm{t}}+\varepsilon_{\mathrm{i}, \mathrm{t}}$

For instance, large settlements may resolve uncertainty among adequately reserved firms that lead them to accrue fewer UTBs, suggesting a negative coefficient on $\gamma_{1}$. At the same time, the enforcement event may revise assessed risk among underreserved firms that lead them to accrue more UTBs relative to adequately reserved firms, suggesting a positive coefficient on $\gamma_{3}$.

To test Hypotheses $4 \mathrm{a}$ and $4 \mathrm{~b}$, I identify non-settlement firms sharing the same external auditor-office as a large-settlement firm and employ Model (1) to test whether they change their tax avoidance surrounding the enforcement outcome. Importantly, I run this model separately for clientele firms depending on whether the settling firm in the auditor's network had adequately reserved for the enforcement outcome. Furthermore, as McGuire, Omer, and Wang (2012) suggest auditors facilitate tax avoidance by providing tax services to their clients, I limit this analysis to clientele firms purchasing tax services from the auditor in the year of the network firm's large settlement.

\subsection{Sample Selection}

To test the effect of large settlements on subsequent tax avoidance, I begin with the 462 large settlement observations from 2002-2011. Because I run my tests on the PRE and POST observations surrounding the settlement year, I restrict this sample to the 2002-2009 observations when defining the POST period over three years and the 2002- 
2011 observations when defining the POST period over one single year. When removing the settlement firm-year $t$ and adding the PRE and POST firm-years, my starting sample ranges from 788 to 2,364 firm-year observations, depending on the specification I use to define the PRE and POST periods. Depending on the specification, I delete 21 to 96 PRE or POST firm-years missing data from Compustat and another 51 to 196 firm-years with an ROA less than 0.5 percent so as to mitigate small denominator concerns. Further, I delete 182 to 687 firm-years in which a second large-settlement observation appears at any point for that firm during the PRE or POST period. ${ }^{18}$ Finally, I delete 84 to 135 observations for which there is not at least one PRE and POST observation for a given settlement firm-year. Depending on the specification, this procedure results in a final sample of 378 to 1,250 firm-years surrounding the large tax settlement. Table 2 documents the sample selection process.

\footnotetext{
${ }^{18}$ In untabulated analysis, there are 120 unique firms with multiple large settlements over the sample period; however, all but 24 of the multiple settlement observations occur within the same three year period, suggesting the settlement is paid out over multiple years or pertains to similar issues in a different taxing jurisdiction. The 24 firm observations remaining are too small a sample to draw inferences regarding any changes in such firms' reserve reporting when a second settlement occurs.
} 


\section{RESULTS}

\subsection{Descriptive Statistics}

Figure 2 graphically depicts the changes in both mean cash and current ETR for adequately reserved and under-reserved firms under the three-year annual specification. The figure shows each group has similar cash and current ETRs during the PRE period and experiences sharp increases in cash ETR in the settlement year. While adequately reserved firms' cash ETRs return to slightly below PRE levels following the settlement year spike, under-reserved firms' cash ETRs are noticeably higher in the POST period. Furthermore, adequately reserved firms enjoy relatively stable current ETRs throughout the measurement window. Under-reserved firms' current ETRs, on the other hand, sharply increase in the settlement year and continue to be higher in the POST period relative to the PRE period and relative to adequately reserved firms in the POST period.

I present descriptive statistics of large settlement firms for the three-year annual specification in Table 3. As seen in Figure 1, the mean cash ETR of adequately reserved (25.7 percent) and under-reserved (25.8 percent) are not statistically different from each other prior to the settlement; however, while adequately reserved firms appear to engage in slightly more levels of tax avoidance following the settlement (cash ETR mean of 23.8 percent), under-reserved firms decrease their tax avoidance levels (cash ETR mean of 30.2 percent) relative to the pre-settlement period. This provides some initial evidence that under-reserved firms revise their expectations of benefits derived from tax avoidance downward following a large settlement, but adequately reserved firms do not.

Table 3 also identifies statistically significant differences in firm characteristics before and after the settlement for both groups, highlighting the importance of 
performing multivariate regressions to control for these factors. Table 4 presents correlation matrices for the three-year annual specification. The magnitudes and statistical significance on my independent variables suggest multicollinearity is not a concern.

\subsection{Multivariate Results}

Table 5 presents multivariate results depicting the effect of large tax settlements on subsequent tax avoidance. The results provide support for Hypothesis 1, as the coefficient on POST in Model 1 is positive and statistically significant $(\mathrm{p}<0.10$ using two-tailed tests) under all three specification. For instance, the results in Column 1 indicate a firm's annual cash ETR is 4.63 percent higher over a three-year POST period relative to the PRE period, reflecting large settlements' economically important impact on firm behavior. ${ }^{19}$ The results also suggest post-examination tax avoidance conditional on a large settlement is distinct from unconditional post-examination tax avoidance, which DeBacker et al. (2013) find increases.

Table 5 also provides support for Hypothesis 2. When adding the UNDERRESERVED indicator variable and interacting this term with the POST indicator, the interaction term in Model 2 is positive in all three sample specifications and statistically significant $(\mathrm{p}<0.10)$ under both annual specifications. Furthermore, the main effect on POST is insignificant in the first two specifications, suggesting that changes in tax avoidance following a large settlement are driven by under-reserved firms. For instance, the results in Column 1 indicate that the increase in a firm's annual cash ETR

\footnotetext{
${ }^{19}$ In untabulated tests, I exclude year $t+1$ from the POST period to alleviate concerns that additional settlement amounts are paid out in the following year that would affect my results. I run a test in which the PRE period includes years $t-3$ and $t-2$ and the POST period includes years $t+2$ and $t+3$. The coefficient on POST remains positive and statistically significant, suggesting the decrease in tax avoidance is not attributable to additional settlement payments made during the POST period.
} 
following a large tax settlement will be 5.66 percentage points higher for an underreserved firm than an adequately reserved firm. This suggests large settlements provide new information to under-reserved firms, leading them to revise their expectations of the benefits derived from tax avoidance and contributing to the behavioral change. Adequately reserved firms, on the other hand, do not adjust their expectations of the benefits derived from tax avoidance following a large settlement because they were previously aware of the tax authority's vigilance and weaknesses of their own positions. This provides a rational explanation for why they do not change their behavior.

Table 6 presents results for my test of Hypothesis 3. While inferences are difficult to draw because the sample contains only 90 observations, the negative and significant coefficient on POST from Model 4 indicates adequately reserved firms report fewer current period UTB accruals following a large settlement. This is consistent with the examination outcome resolving uncertainty surrounding these firms' tax positions and provides some evidence that interactions with the tax authority affect firms' financial reporting, consistent with the guidance outlined in FIN 48.

Relative to adequately reserved firms, the positive and significant coefficient on the interaction term in Model 4 suggests under-reserved firms increase current UTB accruals. The statistical insignificance of the joint test of POST and POST*UNDERRESERVED indicates the settlement does not appear to change their reporting of current UTB accruals overall. I attribute this result to two offsetting effects. First, the results in Table 5 suggest under-reserved firms take less aggressive tax positions on their tax returns following the large settlement, which would ordinarily result in fewer current period UTBs accrued. At the same time, if a large settlement 
revises these firms' expectations of the sustainability of the uncertain positions they continue to take, this would result in greater current UTBs accrued.

Overall, the results underscore the tax authority's role in the financial reporting process. While it appears large tax settlements provide firms with clarity regarding the tax authority's assessment of their tax strategies, the effect on subsequent UTB reporting is conditional on how firms recorded reserves prior to the settlement. I address concerns regarding my limited sample size in sensitivity tests.

Table 7 presents results consistent with my expectations in Hypotheses 4. Specifically, the positive and statistically significant coefficient on POST in the underreserved clientele column suggests that when a firm under-reserves for a large tax settlement, other clientele of that firm's auditor-office subsequently decrease their tax avoidance. This finding highlights the auditor's role as an intermediary that disseminates information regarding the tax authority's vigilance and underscores how the tax authority's enforcement efforts can spillover to affect the behavior of other firms. In untabulated tests, I add an indicator variable equal to one if the clientele firm is in the same industry as the settlement firm and interact this variable with the POST indicator. Although the coefficient on the interaction term is positive, suggesting the decrease in tax avoidance is more pronounced when the clientele and settlement firms are in the same industry, it is not statistically significant at conventional levels.

Importantly, the coefficient on POST in the second column of Table 7 is not statistically significant, indicating that when a firm adequately reserves for a large tax settlement, other clientele of that firm's auditor-office do not subsequently decrease their tax avoidance. This again underscores how the tax authority's efficacy in deterring 
avoidance hinges on its ability to revise others' expectations of the benefits derived from engaging in tax avoidance. A large settlement is less likely to convey new information to a firm's auditor when its client adequately reserved for the enforcement outcome. Consequently, it is less likely an adequately reserved firm's auditor disseminates information regarding the tax authority's vigilance among its network, explaining why its clientele does not appear to change its tax avoidance following the settlement event.

It is unlikely auditors would influence changes in their non-settling clients' tax avoidance if the non-settling clients are cognizant of the tax authority's vigilance and have set up adequate reserves. However, as these non-settling firms have not experienced a large tax settlement and may not have any ongoing tax examinations, I am unable to ascertain to what extent these firms' reserves are adequate. Nevertheless, during the FIN 48 era, I find that firms sharing the same auditor-office as an under-reserved settlement firm accrue more UTBs attributable to prior period positions in the year prior to the network firm's large settlement (untabulated). This suggests certain auditor-offices may have initially underestimated the uncertainty in their clients' tax positions. Knowledge of a pending large settlement at one under-reserved client may then trigger the auditor to reevaluate the expected benefits derived from tax avoidance and influence changes in their non-settling clientele's behavior. 


\section{ADDITIONAL ANALYSIS}

\subsection{Comparison of Adequately Reserved and Under-Reserved Firms}

Although it is difficult to infer why some firms did not adequately reserve for the large settlement, I find that under-reserved are more likely to have an internal control weakness over the tax account than adequately reserved firms in the four years preceding the large settlement (untabulated). This suggests a poor information environment may preclude under-reserved firms' from fully understanding the tax authority's vigilance or weaknesses in their tax positions and thus explain their failure to timely accrue charges for risky tax positions. I argue the large settlement allows under-reserved firms to learn about the tax authority's vigilance and weaknesses in their tax positions, which explains why they modify their behavior more than adequately reserved firms.

Additionally, Gleason and Mills (2011) find that firms purchasing auditorprovided tax services (APTS) adequately reserve for IRS settlements, whereas firms that do not purchase APTS are under-reserved. The authors posit that knowledge spillover from providing tax services enables auditors to more accurately assess their clients' required tax reserves. In the four years leading up to the settlement, I find the frequency and magnitude of APTS is higher among adequately reserved firms in my sample (untabulated). This provides some evidence that information asymmetries between the auditor and tax service provider may explain why firms are under-reserved. Moreover, Panel D of Table 1 indicates that adequately reserved and under-reserved firms are similar in size and most other operational characteristics. Overall, the information environment offers an explanation for why firms under-reserve for large tax settlements 
and why these under-reserved firms change their tax avoidance more than adequately reserved firms following the enforcement outcome.

\subsection{Robustness of Large Settlement Firm Methodology}

To address some of the inherent differences between large settlement and nonsettlement firms observed in Table 1, I employ a propensity-score matching (PSM) technique that seeks to match settlement firms with non-settlement firms based on their observable characteristics. As my findings suggest changes in tax avoidance are concentrated among under-reserved firms, I match adequately and under-reserved settlement firms to non-settlement firms separately. This procedure helps ensure that large settlements, incurred by under-reserved firms in particular, drive changes in reporting as opposed to other firm characteristics. I first regress an indicator variable equal to one for large settlement firms and zero for non-settlement firms on the set of control variables used throughout my tax avoidance tests. Panel A of Appendix C presents the results of this logistic regression.

Next, I match each large settlement firm to a non-settlement control firm without replacement based on the predicted value from the logistic regression, requiring a caliper width of 0.2 times the standard deviation of the logit of the propensity scores. ${ }^{20}$ This procedure enables me to match 245 of the 247 adequately reserved firms and 212 of the 215 under-reserved large-settlement firms. Panel B of Appendix C presents the covariate balance between the propensity-score matched pairs. The statistically insignificant differences indicate my matching procedure sufficiently eliminates the differences in firm characteristics between large settlement and non-settlement firms.

\footnotetext{
${ }^{20}$ Austin (2011) finds this to be the optimal approach for caliper matching.
} 
I then identify the cash-ETR for the large settlement and matched firms before and after year $t$, utilizing the same procedures as my main tests. I further require that the large settlement firm and its matched firm both have observations in the pre and post periods, which, depending on the specification, generates 240 to 865 observations for the adequately reserved sample and their matched firms, and 136 to 601 for the underreserved sample and their matched firms. Finally, I regress the cash ETR on an indicator variable equal to one for the large settlement firms and zero for the matched control firms, an indicator variable equal to one for the POST period (i.e., after year $t$ ) and zero for the PRE period, the interaction of these two variables, and the same set of control variables used in my primary tests. Table 8 presents results of this analysis for each of my specifications.

The insignificant coefficient on LARGE_SETTLER in five of the six regressions indicates that large settlement firms' tax avoidance is not statistically different from the matched control group prior to the enforcement event; however, under-reserved large settlement firms decrease tax avoidance following the enforcement event relative to the matched sample, as evidenced by the positive and statistically significant interaction term across all three specifications. Adequately reserved firms, on the other hand, do not appear to decrease tax avoidance following the enforcement event relative to the matched sample, as evidenced by the statistically insignificant interaction term in two of the three specifications. ${ }^{21}$ These findings provide support that large settlements, incurred by underreserved firms specifically, drive the change in tax avoidance as opposed to other firm characteristics.

\footnotetext{
${ }^{21}$ The coefficient on the interaction term is significantly greater $\left(\chi^{2}<0.05\right)$ in the under-reserved sample than in the adequately reserved sample in two of the three specifications.
} 
To further assess the robustness of my findings, I impose an additional restriction that the cash-ETR must exceed 70 percent in order to classify a firm-year as having a large settlement. ${ }^{22}$ Likewise, I require the current-ETR to exceed 70 percent in order to classify the large settlement firm-year as under-reserved. As a second alternative, I impose a restriction that taxes paid scaled by pre-tax operating cash flows exceed 70 percent. As numerous provisions in the tax code delay or accelerate the recognition of book income or expenses to better match a firm's cash flows, scaling taxes paid by pretax operating cash flows further alleviates some concerns that my methodology identifies firms with large book-tax differences rather than settlements with the tax authority. ${ }^{23}$ The results (untabulated) suggest my findings are generally robust to these more restrictive methodologies.

Lastly, I attempt to validate the observations in my sample by identifying whether the notes in the firm's annual financial statement reference resolutions with the tax authority. Of the 462 firm-years derived from Bauer-Klassen's methodology, I am only able to validate $135 .{ }^{24}$ This does not mean the remaining observations do not have large settlements, but rather that insufficient detail was provided in the financial statements to make a determination. This reflects firms' reluctance to provide detailed disclosures about their tax planning and outcomes (Gleason and Mills 2002; Saavedra 2014).

\footnotetext{
${ }^{22}$ This threshold is similar to the upper bound utilized by Saavedra (2014).

${ }^{23}$ As an example, suppose Firm A has $\$ 300$ of pre-tax operating cash flows and incurs a $\$ 100$ warranty accrual that is not deductible for tax purposes until paid. In this simplified example, Firm A would have pre-tax book income of $\$ 200$, but would pay taxes on $\$ 300$. Assuming a 35\% tax rate, Firm A's cash-ETR would be $52.5 \%$ ( $\$ 300 \times 0.35) / \$ 200$, but its taxes paid scaled by pre-tax operating cash flows would be 35\% $(\$ 300 \times 0.35) / \$ 300$.

${ }^{24}$ This is more than the 54 tax loss events Bauer and Klassen (2014) validate in their sample because that study only considers observations if they are unfavorable relative to a firm's expectation. Consequently, Bauer and Klassen (2014) may not be capturing observations in which the firm had adequately reserved for a large settlement. My validated observations include firm-years that disclose changes in their tax contingency accrual in their effective tax rate reconciliation without providing additional detail. My results on the restricted sample are robust to excluding these firm-years as validated observations.
} 
Nevertheless, the results (untabulated) of this restricted sample using the three-year annual specification are consistent with my main findings that only under-reserved firms decrease tax avoidance following a large settlement. I do not use the restricted sample in my main analysis because it does not provide enough observations to reliably test my hypotheses under the alternative one-year annual or three-year average specifications. Further, this sample does not provide enough observations during the FIN 48 era to test the effect of large settlements on UTB reporting.

\subsection{Robustness of Changes in Financial Reporting}

To address sample size limitations in my test of Hypothesis 3, I seek to identify an alternate methodology for testing how tax examination outcomes affect subsequent UTB reporting. Specifically, I identify 2,660 unique firm-years between 2009 and 2011 that disclose settlements with the tax authority in their UTB tabular rollforward pursuant to FIN 48. I then create a variable, UTB_RETAIN, that utilizes other components from the UTB tabular rollforward to identify the extent to which these firm-years adequately reserved for the settlement. Specifically, I take from the settlement year the sum of decreases in prior period positions attributable to lapses in the statute of limitations (TXTUBSOFLIMIT in Compustat) and other decreases in prior period positions (TXTUBPOSPDEC in Compustat), both representing amounts over-reserved, less increases in prior period positions (TXTUBPOSPINC in Compustat), and scale this value by total beginning of year assets. This variable is similar to the KEEP metric developed in Drake et al. (2014), but subtracts amounts by which the firm had under-reserved (TXTUBPOSPINC) rather than settlement payments (TXTUBSETTLE). I do this so that higher (lower) values of UTB_RETAIN capture firms that had adequately reserved 
(under-reserved) for settlement events. Next, I sort UTB_RETAIN into quintiles by year. In untabulated analysis, I find that the mean value for firms in the highest (lowest) quintile of UTB_RETAIN is $0.006(-0.003)$. The positive sign among the highest quintile suggest these firms actually over-reserved for their settled positions, while the negative sign among the lowest quintile confirms these firms had under-reserved for their settled positions. I then identify CYINC_UTB in years $t-2$ and $t+1$ for each firm-year in the highest and lowest quintiles of UTB_RETAIN. Finally, I regress CYINC_UTB on an indicator variable, LOW_UTB_RETAIN, equal to one if the firm-year is in the lowest quintile of UTB_RETAIN and zero otherwise, a POST indicator, an interaction of these two terms, and the same set of control variables used in Model 4. I present the results of this test in Panel A of Table 9.

Consistent with the results in Table 6, I find that firms in the highest quintile of UTB_RETAIN, which represent adequately, or in this case over-reserved, firms, report fewer UTBs following the settlement (i.e. -0.0017 coefficient on POST). Meanwhile, under-reserved firms, proxied through the LOW_UTB_RETAIN indicator, report fewer UTBs prior to the settlement (i.e., -.0014 coefficient on LOW_UTB_RETAIN) and report higher reserves relative to adequately reserved firms following the settlement (i.e., 0.0008 coefficient on the interaction term). The findings provide further support that firms are complying with FIN 48's mandate to consider interactions with the tax authority in assessing their UTBs. More broadly, this suggests firms learn from tax settlements in a way that shapes their financial reporting over the tax account.

Panel B of Table 9 presents results for an alternative way in which I measure how large tax settlements impact subsequent financial reporting over the tax account. 
Specifically, I run Models 1 and 2 on the same samples used to test Hypotheses 1 and 2, but use CURRENT_ETR as the dependent variable instead of CASH_ETR. The positive and significant coefficient on the interaction term suggests that relative to adequately reserved firms, under-reserved firms increase current taxes accrued for financial reporting purposes following a large settlement. The insignificant coefficient on the POST indicator from Model 2 suggests adequately reserved firms do not change their current tax accruals following a large settlement. 


\section{CONCLUSION}

This study considers how firms change their tax avoidance and financial reporting in response to large tax settlements. My findings provide evidence that large tax settlements deter subsequent tax avoidance, but primarily among firms that had not adequately reserved for the settlement for financial accounting purposes. Further, my results reflect how large settlements affect firms' UTB financial reporting and how this effect varies with firms' financial reporting choices prior to the settlement. Finally, I provide evidence how the tax authority's enforcement efforts can spillover and deter avoidance by other firms when an external auditor appears to disseminate information learned from a large settlement to its other clientele.

Overall, this study provides context to the situations in which the tax authority's enforcement deters tax avoidance and affects subsequent reporting. In particular, I demonstrate that firms with poorer information environments appear to learn from large settlements in a way that decreases their expectations of the benefits derived from tax avoidance, leading them to change their behavior in an expected manner. On the other hand, firms with stronger information environments appear to learn less from large settlements about weaknesses in their positions or the tax authority's vigilance, such that the enforcement outcome does not trigger a change in behavior. As large settlements have less of a deterrent effect among adequately reserved firms, my findings should inform tax authorities to closely monitor these firms in particular following an enforcement outcome. Although large settlements do not necessarily affect firms' subsequent tax avoidance, the resolution still provides clarity that affects their subsequent financial accounting for taxes. In instances when large settlements appear to deter tax avoidance, I 
show how the tax authority's enforcement efforts can indirectly affect other firms' tax avoidance as well. In particular, I highlight the importance of external auditors in communicating information learned through the tax authority's enforcement efforts and this intermediaries' ability to influence other clients' tax avoidance choices conditional on the information learned. 


\title{
APPENDIX A: VARIABLE DEFINITIONS
}

\author{
CASH_ETR= \\ CURRENT_ETR= \\ CYINC_UTB= \\ POST $=$ \\ LARGE_SETTLER= \\ UNDERRESERVED= \\ UTB_RETAIN $=$ \\ $L O W \_U T B \_R E T A I N=$ \\ $S I Z E=$ \\ LEVERAGE $=$ \\ $C A P X=$ \\ INV_INTENSITY= \\ RD_INTENSITY= \\ $R O A=$ \\ FOREIGN_INCOME= \\ $N O L=$ \\ $B I G \_N=$ \\ Taxes paid divided by pretax income less special items \\ Current tax expense divided by pretax income less special items \\ Current year increase for current period unrecognized tax benefits less \\ current year decrease for current period unrecognized tax benefits \\ divided by beginning of year total assets \\ Indicator variable equal to one if the year is after the large settlement \\ and zero otherwise \\ Indicator variable equal to one if a firm had a large settlement with \\ the tax authority, proxied by firm-years whose cash ETR exceeds \\ their ten year mean by more than two industry standard deviations \\ Indicator variable equal to one if a firm did not adequately reserve for \\ its large settlement for financial accounting purposes, and zero \\ otherwise. \\ Sum of decrease in UTBs for prior period positions and statute of \\ limitation expirations less increases in UTBs for prior period \\ positions, divided by beginning of year total assets \\ Indicator variable equal to one if the firm is in the lowest quintile of \\ $U T B \_R E T A I N$ in a given year, and zero otherwise \\ Natural logarithm of total assets \\ Long-term liabilities divided by total assets \\ Capital expenditures divided by beginning of year total assets \\ Inventory divided by beginning of year total assets \\ Research expenditures divided by beginning of year total assets \\ Pretax income less special items, divided by total assets \\ Pretax foreign income divided by beginning of year total assets \\ Indicator variable equal to one if the firm has a tax loss carryforward, \\ and zero otherwise \\ Indicator variable equal to one if the firm engages a Big_N auditor, \\ and zero otherwise
}




\section{APPENDIX B: FIN 48 TABULAR ROLLFORWARD}

Below is an example of the required disclosure of Air Products \& Chemicals, Inc. 2011 FIN 48 tabular rollforward.

\begin{tabular}{lccc} 
Unrecognized Tax Benefits & 2011 & 2010 & 2009 \\
\hline Balance at beginning of year & $\$ 197.8$ & $\$ 163.1$ & $\$ 154.7$ \\
Additions for tax positions of the current year & 16.3 & 31.8 & 23.6 \\
Additions for tax positions of prior years & 5.7 & 12.9 & 36.3 \\
Reductions for tax positions of prior years & $\mathbf{1 7 2 . 4 )}$ & $(1.0)$ & $(43.5)$ \\
Settlements & $(15.6)$ & - & $(4.9)$ \\
Statute of limitations expiration & $(4.8)$ & $(6.1)$ & $(5.4)$ \\
Foreign currency translation & $\mathbf{1 0 . 6 )}$ & $(2.9)$ & 2.3 \\
\hline Balance at End of Year & $\$ 126.4$ & $\$ 197.8$ & $\$ 163.1$ \\
\hline
\end{tabular}

All components that reduce the unrecognized tax benefit (UTB) liability are presented as positive amounts in the Compustat database, so I define the UTB_RETAIN using the following formula: (Reductions for tax positions of prior years + Statute of limitations expiration - Additions for tax positions of prior years)/Total assets at the beginning of the year.

In my tests of Hypothesis 3, the additions for tax positions of the current year (i.e. 16.3 for the aforementioned company in 2011), scaled by beginning of year total assets, is the dependent variable. 


\section{APPENDIX C: PROPENSITY-SCORE MATCHING ANALYSIS}

Panel A: Propensity to Have a Large Settlement

\begin{tabular}{|c|c|c|}
\hline $\begin{array}{l}\text { DEPENDENT VARIABLE= } \\
\text { LARGE_SETTLER }\end{array}$ & Adequately reserved (i) & Under-reserved (ii) \\
\hline SIZE & $\begin{array}{c}-0.0822^{*} \\
(-1.90)\end{array}$ & $\begin{array}{c}-0.1126^{* *} \\
(-2.36)\end{array}$ \\
\hline LEVERAGE & $\begin{array}{c}-1.7281 * * * \\
(-3.48)\end{array}$ & $\begin{array}{c}-1.2848^{* *} \\
(-2.55)\end{array}$ \\
\hline CAPX_SCALE & $\begin{array}{l}1.5914 \\
(1.44)\end{array}$ & $\begin{array}{l}1.7385 \\
(1.57)\end{array}$ \\
\hline INV_INTENSITY & $\begin{array}{c}0.4399 \\
(0.92)\end{array}$ & $\begin{array}{l}0.7507 \\
(1.55)\end{array}$ \\
\hline RD_INTENSITY & $\begin{array}{r}-0.7371 \\
(-0.39)\end{array}$ & $\begin{array}{r}-1.3800 \\
(-0.63)\end{array}$ \\
\hline$R O A$ & $\begin{array}{l}-14.3839 * * * \\
(-9.52)\end{array}$ & $\begin{array}{c}-26.0949 * * * \\
(-12.43)\end{array}$ \\
\hline FOREIGN_INCOME & $\begin{array}{c}-5.6666 * * * \\
(-2.89)\end{array}$ & $\begin{array}{l}-2.7251 \\
(-1.21)\end{array}$ \\
\hline$N O L$ & $\begin{array}{c}-0.0305 \\
(-0.21)\end{array}$ & $\begin{array}{c}0.0405 \\
(0.26)\end{array}$ \\
\hline$B I G \_N$ & $\begin{array}{c}0.0306 \\
(0.15)\end{array}$ & $\begin{array}{c}0.1350 \\
(0.58)\end{array}$ \\
\hline INTERCEPT & $\begin{array}{c}-2.0294 * * * \\
(-4.10)\end{array}$ & $\begin{array}{c}-1.1285^{* *} \\
(-2.29)\end{array}$ \\
\hline $\begin{array}{l}\mathrm{N} \\
\text { Fixed Effects } \\
\text { Cluster }\end{array}$ & $\begin{array}{c}8,388 \\
\text { Ind\&Yr } \\
\text { N/A }\end{array}$ & $\begin{array}{c}8,428 \\
\text { Ind\&Yr } \\
\text { N/A }\end{array}$ \\
\hline Adjusted $\mathrm{R}^{2}$ & 0.0911 & 0.171 \\
\hline
\end{tabular}


APPENDIX C CONTINUED: PROPENSITY-SCORE MATCHING ANALYSIS

Panel B: Covariate Balance between the Propensity-Score Matched Pairs

\begin{tabular}{lcccccc} 
& $\begin{array}{c}\text { Adequately } \\
\text { Reserved } \\
(\mathrm{N}=245)\end{array}$ & $\begin{array}{c}\text { Control } \\
(\mathrm{N}=245)\end{array}$ & $\begin{array}{c}\text { DIFF IN } \\
\text { MEAN } \\
\text { Value })\end{array}$ & $\begin{array}{c}\text { Under- } \\
\text { reserved } \\
(\mathrm{N}=212)\end{array}$ & $\begin{array}{c}\text { Control } \\
(\mathrm{N}=212)\end{array}$ & $\begin{array}{c}\text { DIFF IN } \\
\text { MEAN } \\
\text { Value }\end{array}$ \\
\cline { 2 - 7 } SIZE & 6.920 & 6.933 & 0.9378 & 6.933 & 6.919 & 0.9426 \\
LEVERAGE & 0.154 & 0.136 & 0.1776 & 0.180 & 0.186 & 0.7499 \\
CAPX_SCALE & 0.056 & 0.056 & 0.9502 & 0.060 & 0.068 & 0.3137 \\
INV_INTENSITY & 0.156 & 0.148 & 0.5758 & 0.158 & 0.155 & 0.861 \\
ROA & 0.074 & 0.079 & 0.3756 & 0.056 & 0.059 & 0.5574 \\
FOREIGN_INCOME & 0.012 & 0.013 & 0.7818 & 0.010 & 0.007 & 0.5205 \\
NOL & 0.380 & 0.355 & 0.5749 & 0.406 & 0.387 & 0.6921 \\
BIG_N & 0.837 & 0.849 & 0.7103 & 0.840 & 0.849 & 0.7894
\end{tabular}

Notes: Panel A presents results of a logistic regression estimating the probability that a firm experienced a large settlement. The first (second) column estimates the probability of an adequately reserved (under-reserved) large settlement event. All variables are defined in Appendix A. T-statistics are reported in parentheses below coefficient estimates. The symbols *, **, and *** denote statistical significance at the $0.10,0.05$, and 0.01 levels, respectively using two-tailed tests. Industry (Fama-French 17) and year fixed effects are applied. Panel B presents covariate balances for the propensity score matched pairs. 
APPENDIX D: FIGURES

FIGURE 1 TIMELINE OF MEASUREMENT PERIOD ..................... 54

FIGURE 2 CHANGES IN REPORTING AROUND LARGE TAX SETTLEMENTS .......................................... 55 
Figure 1

Timeline of Measurement Period

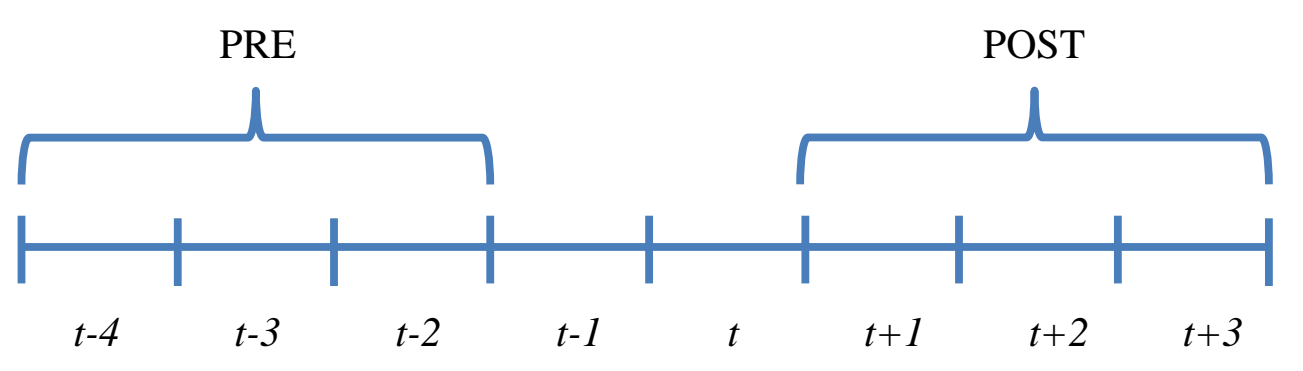

(i) Three year annual specification

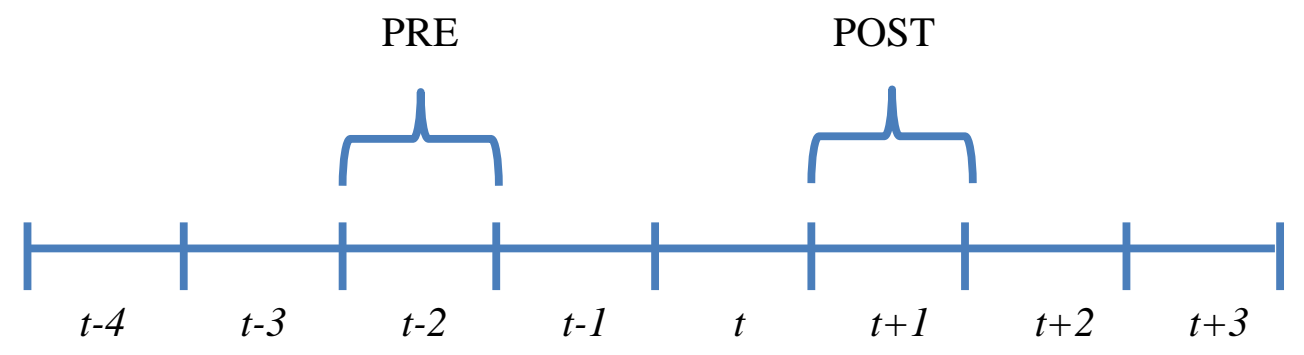

(ii) One-year annual specification

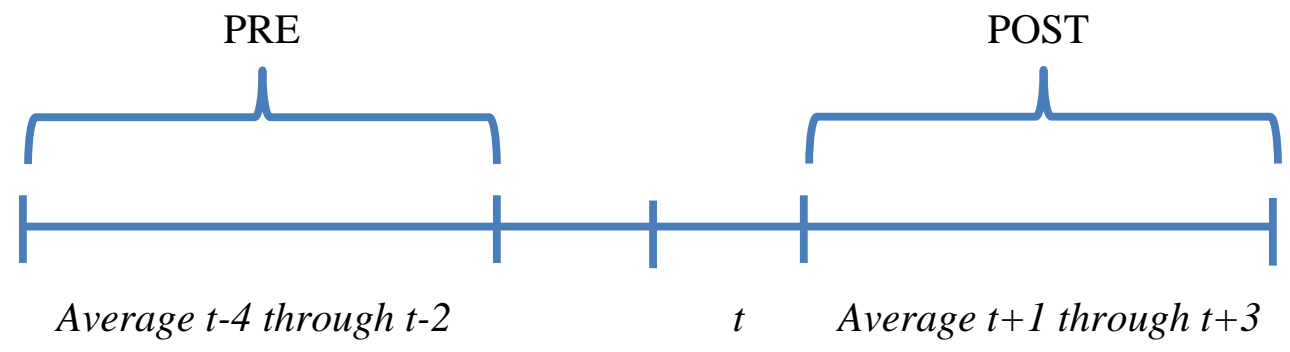

(iii) Three-year average specification 
Figure 2

Changes in Reporting Around Large Tax Settlements

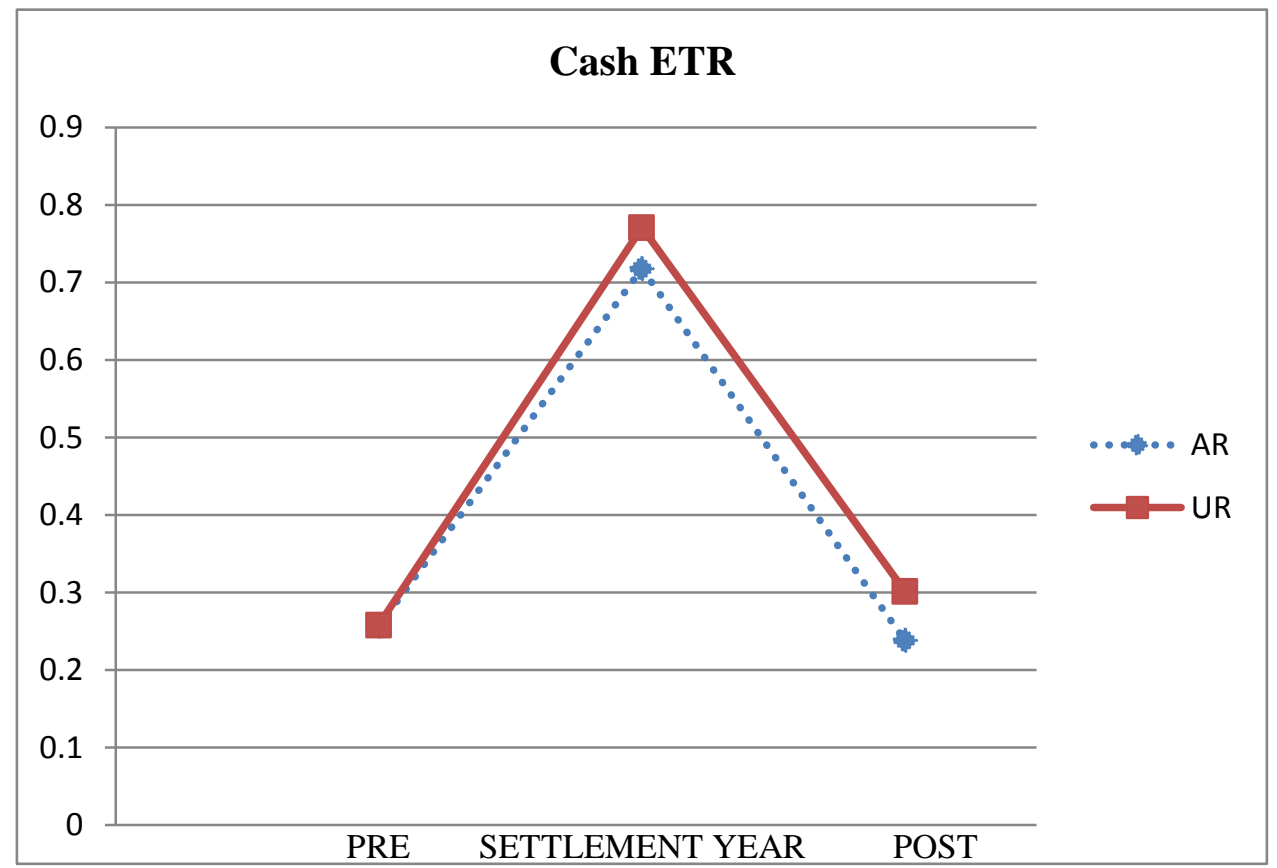

The above chart depicts the mean annual cash ETRs for adequately reserved (AR) and under-reserved firms (UR) in the PRE and POST periods using the three-year annual specification, as well as the mean cash ETR in the settlement year.

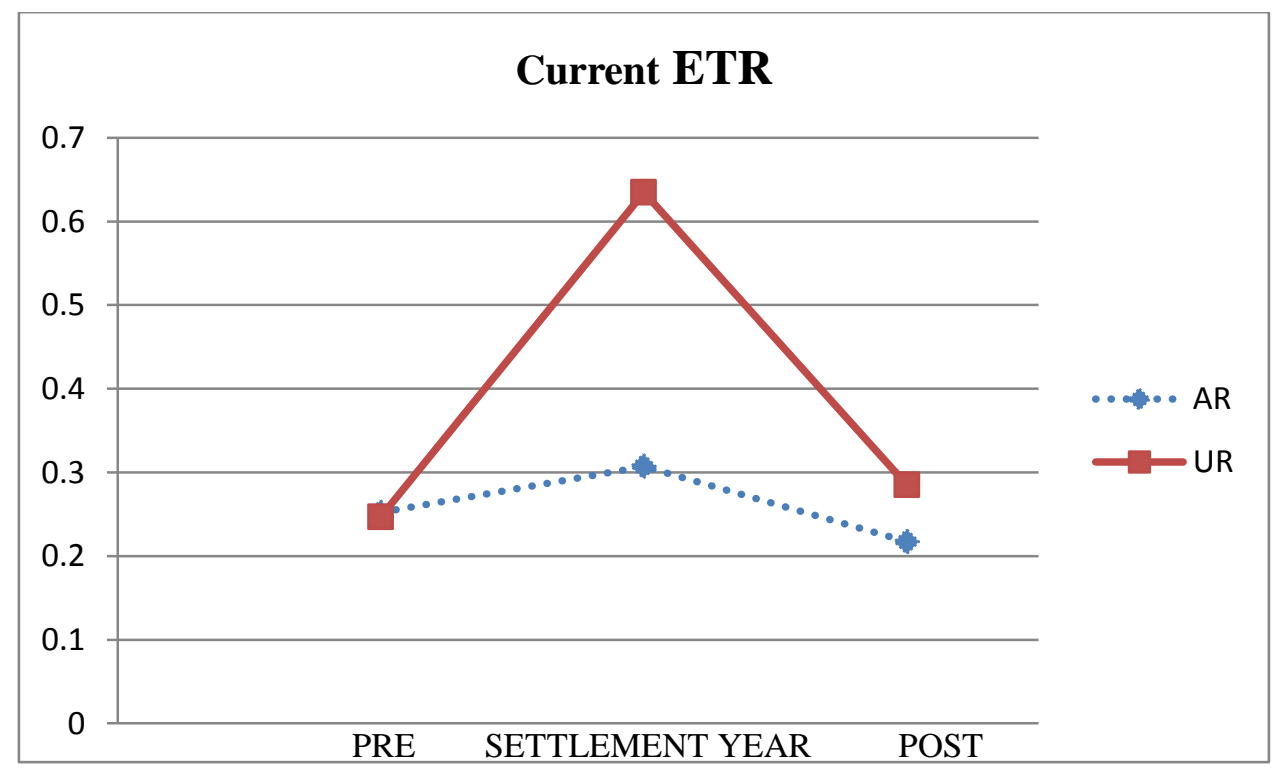

The above chart depicts the mean annual current ETR for adequately reserved (AR) and under-reserved firms (UR) in the PRE and POST periods using the three-year annual specification, as well as the mean cash ETR in the settlement year. 
APPENDIX E: TABLES

Table $1 \quad$ Large Settlement Firm-Years ................................... 57

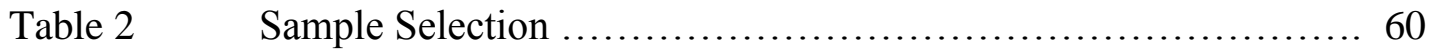

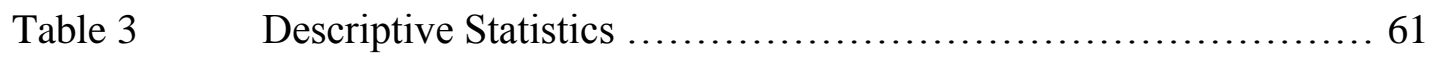

Table $4 \quad$ Correlation Matrix ............................................. 62

Table 5 Effects of Large Settlements on Tax Avoidance .................. 63

Table $6 \quad$ Effects of Large Settlements on UTB Reporting ................... 64

Table 7 Effects of Large Settlements on Other Firms' Tax Avoidance in The External Auditor's Clientele ................................. 65

Table 8 Effect of Large Settlements on Tax Avoidance Robustness Test ... 66

Table 9 Effect of Large Settlements on Financial Reporting over the Tax Account .................................................... 67 
Table 1

Large Settlement Firm-Years

\section{Panel A: Determination of Large Settlement Firms}

Public firms in Compustat with Industry Information, 2002-2011

78,382

Less: observations with negative pre-tax book income or missing cash taxes paid

$(35,154)$

Less: observations with an ROA less than $0.5 \%$

Less: observations without ten years of consecutive data to measure cash and current

ETR benchmarks

Less: observations in the banking or regulated industries

Initial sample

8,675

Large settlement firm-years

462

\section{Panel B: Frequency of Large Tax Settlements}

\begin{tabular}{cccccc} 
Year & $\begin{array}{c}\text { Total } \\
\text { Observations }\end{array}$ & $\begin{array}{c}\text { Total Large } \\
\text { Settlements }\end{array}$ & $\begin{array}{c}\text { Large } \\
\text { Settlements } \\
\text { Adequately } \\
\text { Reserved }\end{array}$ & $\begin{array}{c}\text { Large Settlements } \\
\text { Under-reserved }\end{array}$ & $\begin{array}{c}\text { Percent Under- } \\
\text { reserved }\end{array}$ \\
\hline 2002 & 826 & 34 & 18 & 16 & $47.06 \%$ \\
2003 & 850 & 27 & 14 & 13 & $48.15 \%$ \\
2004 & 913 & 33 & 18 & 15 & $45.45 \%$ \\
2005 & 931 & 53 & 25 & 28 & $52.83 \%$ \\
2006 & 909 & 65 & 33 & 32 & $49.23 \%$ \\
2007 & 864 & 59 & 33 & 26 & $44.07 \%$ \\
2008 & 828 & 72 & 38 & 34 & $47.22 \%$ \\
2009 & 801 & 51 & 26 & 25 & $49.02 \%$ \\
2010 & 851 & 40 & 28 & 12 & $30.00 \%$ \\
2011 & 902 & 28 & 14 & 14 & $50.00 \%$ \\
\hline Total & 8,675 & 462 & 247 & 215 & $46.54 \%$
\end{tabular}


Table 1 continued

Large Settlement Firm-Years

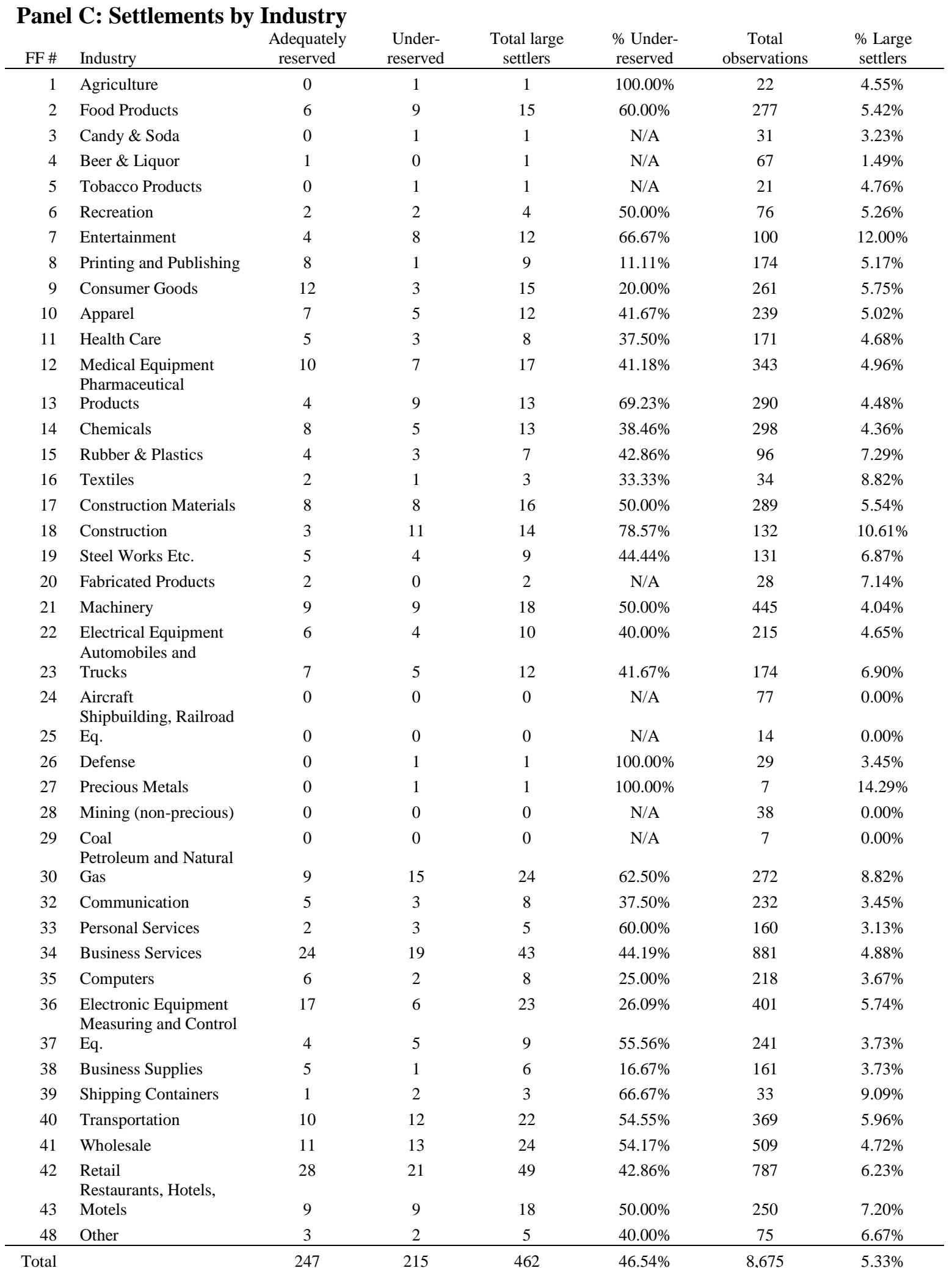


Table 1 continued

Large Settlement Firm-Years

\section{Panel D: Descriptives of Large Tax Settlements}

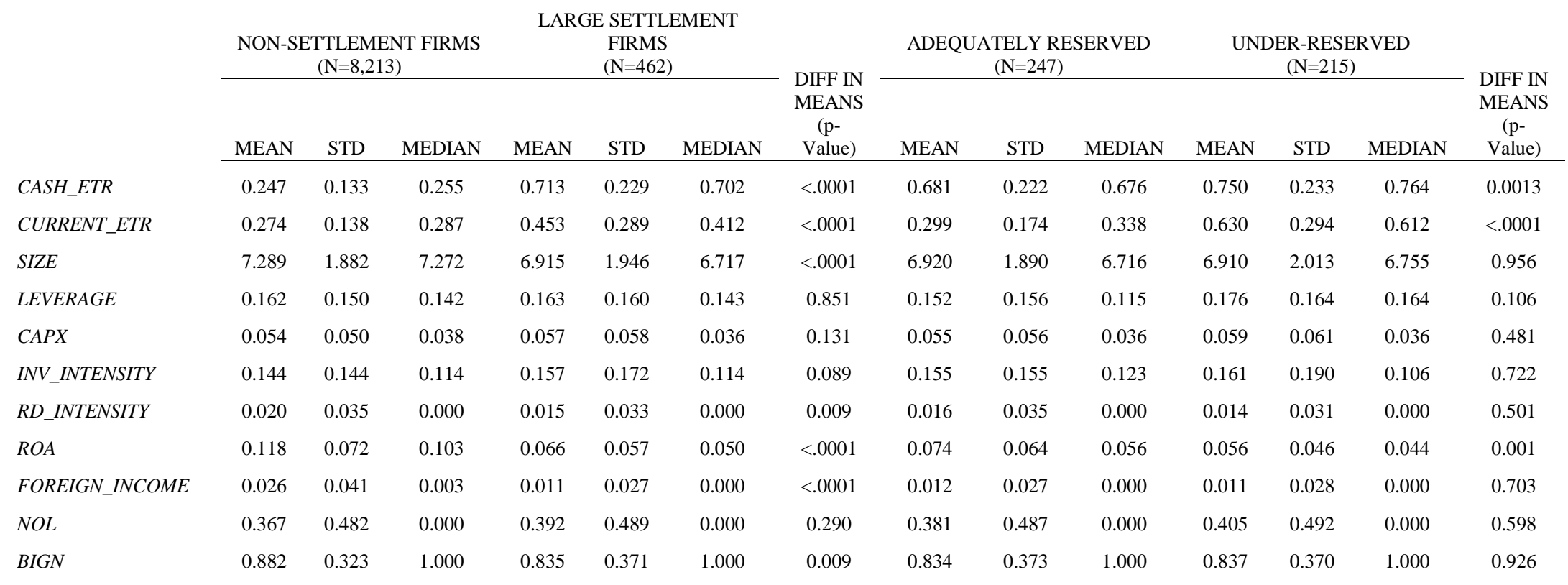

Notes: Panel A presents the procedure used to identify large settlement firms. Panel B identifies the frequency of large tax settlements by year, separately showing the number of observations in which firms adequately reserved or under-reserved for the settlement. Panel C identifies the frequency of large tax settlements by industry (Fama French 48), separately showing the number of observations in which firms adequately reserved or under-reserved for the settlement. Panel D presents descriptive statistics for the non-settlement firms and settlement firms, and separate descriptive statistics for adequately reserved and under-reserved large-settlement firms. All variables are defined in Appendix A. All continuous variables are winsorized at the 1 and 99 percent levels by year, except cash ETR and current ETR, which are truncated at 0 and 1. 
Table 2

Sample Selection

\begin{tabular}{l} 
SPECIFICATION \\
\cline { 2 - 4 } \\
\cline { 2 - 4 }
\end{tabular}


Table 3

Descriptive Statistics

\begin{tabular}{|c|c|c|c|c|c|c|c|c|c|c|c|c|c|c|c|c|}
\hline \multirow[b]{4}{*}{ CASH_ETR } & \multicolumn{7}{|c|}{ ADEQUATELYRESERVED (AR) } & \multicolumn{7}{|c|}{ UNDER-RESERVED (UR) } & \multicolumn{2}{|c|}{ ARvs. UR } \\
\hline & \multicolumn{3}{|c|}{ PREN=402 } & \multicolumn{3}{|c|}{ POST N=339 } & \multirow{2}{*}{$\begin{array}{l}\text { DIFFIN - } \\
\text { MEAN } \\
\text { (p-Value) }\end{array}$} & \multicolumn{3}{|c|}{ PREN=276 } & \multicolumn{3}{|c|}{ POST N=233 } & \multirow{2}{*}{$\begin{array}{l}\text { DIFF IN } \\
\text { MEAN } \\
\text { (p-Value) }\end{array}$} & PRE & POST \\
\hline & MEAN & STD & MEDIAN & MEAN & STD & MEDIAN & & MEAN & STD & MEDIAN & MEAN & STD & MEDIAN & & $\begin{array}{r}\text { DIFFI } \\
\quad \text { p- }\end{array}$ & $\begin{array}{l}\text { MEAN } \\
\text { ue) }\end{array}$ \\
\hline & 0.257 & 0.127 & 0.258 & 0.238 & 0.156 & 0.231 & 0.077 & 0.258 & 0.164 & 0.257 & 0.302 & 0.186 & 0.298 & 0.006 & 0.895 & $<.0001$ \\
\hline CURRENT_ETR & 0.252 & 0.171 & 0.287 & 0.217 & 0.184 & 0.216 & 0.008 & 0.247 & 0.169 & 0.271 & 0.285 & 0.202 & 0.290 & 0.023 & 0.703 & $<.0001$ \\
\hline SIZE & 6.825 & 1.955 & 6.571 & 7.353 & 1.919 & 7.206 & 0.000 & 6.853 & 1.785 & 6.729 & 7.261 & 1.875 & 7.217 & 0.012 & 0.849 & 0.572 \\
\hline LEVERAGE & 0.147 & 0.123 & 0.136 & 0.171 & 0.157 & 0.143 & 0.020 & 0.176 & 0.155 & 0.154 & 0.160 & 0.148 & 0.145 & 0.244 & 0.007 & 0.405 \\
\hline CAPX & 0.070 & 0.065 & 0.052 & 0.056 & 0.058 & 0.038 & 0.001 & 0.071 & 0.065 & 0.053 & 0.054 & 0.055 & 0.036 & 0.002 & 0.963 & 0.770 \\
\hline INV_INTENSITY & 0.161 & 0.152 & 0.119 & 0.139 & 0.134 & 0.098 & 0.035 & 0.153 & 0.157 & 0.117 & 0.127 & 0.126 & 0.104 & 0.042 & 0.480 & 0.289 \\
\hline RD_INTENSITY & 0.020 & 0.043 & 0.000 & 0.022 & 0.046 & 0.000 & 0.517 & 0.018 & 0.040 & 0.000 & 0.019 & 0.042 & 0.000 & 0.797 & 0.520 & 0.383 \\
\hline$R O A$ & 0.128 & 0.070 & 0.116 & 0.086 & 0.054 & 0.076 & $<.0001$ & 0.108 & 0.066 & 0.090 & 0.092 & 0.060 & 0.078 & 0.004 & 0.000 & 0.295 \\
\hline FOREIGN_INCOME & 0.020 & 0.036 & 0.000 & 0.018 & 0.030 & 0.000 & 0.507 & 0.023 & 0.040 & 0.003 & 0.026 & 0.041 & 0.005 & 0.432 & 0.247 & 0.012 \\
\hline NOL & 0.296 & 0.457 & 0.000 & 0.404 & 0.491 & 0.000 & 0.002 & 0.359 & 0.480 & 0.000 & 0.502 & 0.501 & 1.000 & 0.001 & 0.086 & 0.020 \\
\hline BIGN & 0.896 & 0.306 & 1.000 & 0.835 & 0.372 & 1.000 & 0.017 & 0.938 & 0.241 & 1.000 & 0.871 & 0.336 & 1.000 & 0.009 & 0.052 & 0.223 \\
\hline
\end{tabular}

Notes: This table presents descriptive statistics for the variables in my sample using the three-year annual specification. All variables are defined in Appendix A. All continuous variables are winsorized at the 1 and 99 percent levels, except cash ETR and current ETR, which are truncated at 0 and 1. 
Table 4

Correlation Matrix

\begin{tabular}{|c|c|c|c|c|c|c|c|c|c|c|c|c|c|c|}
\hline \\
\hline & & 1 & 2 & 3 & 4 & 5 & 6 & 7 & 8 & 9 & 10 & 11 & 12 & 13 \\
\hline 1 & CASH_ETR & & 0.455 & 0.006 & 0.081 & -0.067 & -0.069 & 0.055 & 0.078 & -0.119 & 0.151 & -0.058 & -0.119 & 0.013 \\
\hline 2 & CURRENT_ETR & 0.414 & & -0.034 & 0.074 & -0.188 & -0.118 & 0.000 & 0.085 & -0.129 & 0.164 & -0.194 & -0.139 & -0.011 \\
\hline 3 & POST & 0.022 & -0.014 & & 0.000 & 0.127 & 0.006 & -0.177 & -0.065 & 0.023 & -0.250 & 0.032 & 0.126 & -0.099 \\
\hline 4 & UNDERRESERVED & 0.094 & 0.077 & 0.000 & & -0.007 & 0.022 & 0.014 & -0.047 & -0.009 & -0.069 & 0.067 & 0.080 & 0.061 \\
\hline 5 & SIZE & -0.045 & -0.179 & 0.125 & -0.007 & & 0.338 & 0.120 & -0.244 & 0.064 & -0.156 & 0.325 & 0.246 & 0.399 \\
\hline 6 & LEVERAGE & -0.047 & -0.083 & 0.027 & 0.036 & 0.269 & & 0.072 & -0.062 & -0.190 & -0.297 & 0.029 & 0.075 & 0.126 \\
\hline 7 & CAPX & -0.031 & -0.063 & -0.126 & -0.004 & 0.069 & 0.026 & & -0.093 & -0.210 & 0.193 & -0.049 & -0.094 & 0.152 \\
\hline 8 & INV_INTENSITY & 0.048 & 0.114 & -0.082 & -0.034 & -0.266 & -0.061 & -0.127 & & 0.094 & 0.047 & 0.021 & -0.089 & -0.163 \\
\hline 9 & RD_INTENSITY & -0.142 & -0.070 & 0.019 & -0.030 & 0.002 & -0.192 & -0.169 & -0.096 & & 0.021 & 0.310 & 0.028 & -0.025 \\
\hline 10 & $R O A$ & 0.011 & 0.074 & 0.000 & -0.091 & -0.061 & -0.025 & -0.029 & 0.229 & -0.020 & 0.117 & -0.140 & -0.054 & -0.050 \\
\hline 11 & FOREIGN_INCOME & 0.074 & 0.076 & -0.236 & -0.064 & -0.173 & -0.287 & 0.148 & 0.050 & 0.076 & & -0.004 & -0.173 & -0.016 \\
\hline 12 & $N O L$ & -0.023 & -0.154 & 0.003 & 0.074 & 0.262 & -0.049 & -0.007 & -0.028 & 0.183 & 0.131 & & 0.228 & 0.168 \\
\hline 13 & $B I G N$ & 0.076 & 0.101 & -0.084 & 0.035 & -0.077 & -0.108 & 0.158 & 0.023 & -0.170 & 0.117 & 0.033 & -0.145 & -0.077 \\
\hline
\end{tabular}

Notes: Spearman (Pearson) correlation coefficients appear above (below) the diagonal for each of the variables using the three-year annual specification. Correlations highlighted in bold are significant at $\mathrm{p}<0.1$. All variables are defined in Appendix A. All continuous variables are winsorized at the 1 and 99 percent levels, except cash and current ETR, which are truncated at 0 and 1 . 
Table 5

Effect of Large Settlements on Tax Avoidance

\begin{tabular}{|c|c|c|c|c|c|c|}
\hline \multirow[b]{2}{*}{$\begin{array}{l}\text { DEPENDENT } \\
\text { VARIABLE }=C A S H \_E T R\end{array}$} & \multicolumn{2}{|c|}{$\begin{array}{c}3-\text { Years }(\mathrm{t}-4 \text { to } \mathrm{t}-2 \text { and } \mathrm{t}+1 \\
\text { to } \mathrm{t}+3)(\mathrm{i})\end{array}$} & \multicolumn{2}{|c|}{ 1-Year $(\mathrm{t}-2$ and $\mathrm{t}+1)$ (ii) } & \multicolumn{2}{|c|}{ 3-Year Average (iii) } \\
\hline & Model (1) & Model (2) & Model (1) & Model (2) & Model (1) & Model (2) \\
\hline POST & $\begin{array}{l}0.0463 * * * \\
\quad(2.74)\end{array}$ & $\begin{array}{l}0.0208 \\
(1.08)\end{array}$ & $\begin{array}{l}0.0527 * * * \\
\quad(3.13)\end{array}$ & $\begin{array}{c}0.0172 \\
(0.85)\end{array}$ & $\begin{array}{c}0.0753 * * * \\
(2.71)\end{array}$ & $\begin{array}{c}0.0624 * * \\
(2.07)\end{array}$ \\
\hline UNDERRESERVED & & $\begin{array}{r}0.0071 \\
(0.48)\end{array}$ & & $\begin{array}{r}0.0165 \\
(0.84)\end{array}$ & & $\begin{array}{c}0.0074 \\
(0.34)\end{array}$ \\
\hline POST*UNDERRESERVED & & $\begin{array}{c}0.0566 * * * \\
(2.84)\end{array}$ & & $\begin{array}{c}0.0821 * * * \\
(3.00)\end{array}$ & & $\begin{array}{c}0.0356 \\
(1.19)\end{array}$ \\
\hline SIZE & $\begin{array}{l}-0.0024 \\
(-0.49)\end{array}$ & $\begin{array}{l}-0.0015 \\
(-0.32)\end{array}$ & $\begin{array}{l}-0.0036 \\
(-0.75)\end{array}$ & $\begin{array}{l}-0.0021 \\
(-0.44)\end{array}$ & $\begin{array}{l}-0.0071 \\
(-1.31)\end{array}$ & $\begin{array}{l}-0.0064 \\
(-1.19)\end{array}$ \\
\hline LEVERAGE & $\begin{array}{l}-0.0497 \\
(-1.07)\end{array}$ & $\begin{array}{l}-0.0502 \\
(-1.08)\end{array}$ & $\begin{array}{l}0.0027 \\
(0.05)\end{array}$ & $\begin{array}{r}0.0006 \\
(0.01)\end{array}$ & $\begin{array}{l}-0.0774 \\
(-1.34)\end{array}$ & $\begin{array}{l}-0.0776 \\
(-1.35)\end{array}$ \\
\hline CAPX_SCALE & $\begin{array}{c}-0.2051 * * \\
(-2.07)\end{array}$ & $\begin{array}{c}-0.1812 * \\
(-1.82)\end{array}$ & $\begin{array}{l}-0.1220 \\
(-0.84)\end{array}$ & $\begin{array}{l}-0.0799 \\
(-0.56)\end{array}$ & $\begin{array}{c}-0.4164 * * \\
(-2.33)\end{array}$ & $\begin{array}{c}-0.3859 * * \\
(-2.16)\end{array}$ \\
\hline INV_INTENSITY & $\begin{array}{c}0.0408 \\
(1.00)\end{array}$ & $\begin{array}{c}0.0426 \\
(1.01)\end{array}$ & $\begin{array}{l}0.0405 \\
(0.62)\end{array}$ & $\begin{array}{c}0.0576 \\
(0.90)\end{array}$ & $\begin{array}{r}0.0945 \\
(1.42)\end{array}$ & $\begin{array}{c}0.0940 \\
(1.41)\end{array}$ \\
\hline RD_INTENSITY & $\begin{array}{c}-0.7234 * * * \\
(-3.99)\end{array}$ & $\begin{array}{c}-0.7068 * * * \\
(-3.91)\end{array}$ & $\begin{array}{c}-0.8745 * * * \\
(-3.60)\end{array}$ & $\begin{array}{c}-0.8292 * * * \\
(-3.49)\end{array}$ & $\begin{array}{c}-0.8536 * * * \\
(-3.66)\end{array}$ & $\begin{array}{c}-0.8538 * * * \\
(-3.68)\end{array}$ \\
\hline$R O A$ & $\begin{array}{c}0.2092 * * \\
(2.40)\end{array}$ & $\begin{array}{c}0.2079 * * \\
(2.48)\end{array}$ & $\begin{array}{c}0.2182 * \\
(1.69)\end{array}$ & $\begin{array}{c}0.2415^{*} \\
(1.91)\end{array}$ & $\begin{array}{r}0.1373 \\
(1.03)\end{array}$ & $\begin{array}{l}0.1269 \\
(0.95)\end{array}$ \\
\hline FOREIGN_INCOME & $\begin{array}{l}0.1652 \\
(0.88)\end{array}$ & $\begin{array}{l}0.1076 \\
(0.57)\end{array}$ & $\begin{array}{l}0.2046 \\
(0.87)\end{array}$ & $\begin{array}{l}0.1203 \\
(0.52)\end{array}$ & $\begin{array}{l}0.1119 \\
(0.46)\end{array}$ & $\begin{array}{l}0.0693 \\
(0.28)\end{array}$ \\
\hline NOL & $\begin{array}{c}-0.0295 * * \\
(-2.09)\end{array}$ & $\begin{array}{c}-0.0332 * * \\
(-2.40)\end{array}$ & $\begin{array}{c}-0.0202 \\
(-1.35)\end{array}$ & $\begin{array}{c}-0.0264 * \\
(-1.80)\end{array}$ & $\begin{array}{c}-0.0256 \\
(-1.49)\end{array}$ & $\begin{array}{l}-0.0279 \\
(-1.63)\end{array}$ \\
\hline$B I G \_N$ & $\begin{array}{l}0.0275 \\
(1.42)\end{array}$ & $\begin{array}{l}0.0238 \\
(1.24)\end{array}$ & $\begin{array}{l}0.0208 \\
(0.87)\end{array}$ & $\begin{array}{c}0.0172 \\
(0.74)\end{array}$ & $\begin{array}{l}0.0463 \\
(1.64)\end{array}$ & $\begin{array}{l}0.0437 \\
(1.55)\end{array}$ \\
\hline INTERCEPT & $\begin{array}{c}0.2626 * * * \\
(6.25)\end{array}$ & $\begin{array}{c}0.2536 * * * \\
(6.03)\end{array}$ & $\begin{array}{c}0.1518 * * \\
(2.39)\end{array}$ & $\begin{array}{c}0.1312 * * \\
(2.08)\end{array}$ & $\begin{array}{c}0.2239 * * * \\
(3.22)\end{array}$ & $\begin{array}{c}0.2151 * * * \\
(3.05)\end{array}$ \\
\hline $\begin{array}{l}\text { POST }+ \\
\text { POST }^{*} U N D E R R E S E R V E D\end{array}$ & & $\begin{array}{c}0.0774 * * * \\
(14.21)\end{array}$ & & $\begin{array}{c}0.0993 * * * \\
(19.06)\end{array}$ & & $\begin{array}{c}0.0980 * * * \\
(8.84)\end{array}$ \\
\hline $\begin{array}{l}\text { UNDERRESERVED + } \\
P O S T^{*} U N D E R R E S E R V E D\end{array}$ & & $\begin{array}{c}0.0637 * * * \\
(13.43)\end{array}$ & & $\begin{array}{c}0.0986 * * * \\
(21.02)\end{array}$ & & $\begin{array}{c}0.0430 * * \\
(4.09)\end{array}$ \\
\hline $\mathrm{N}$ & 1,250 & 1,250 & 564 & 564 & 378 & 378 \\
\hline $\begin{array}{l}\text { Fixed Effects } \\
\text { Cluster }\end{array}$ & $\begin{array}{l}\text { Ind\&Yr } \\
\text { Firm }\end{array}$ & $\begin{array}{l}\text { Ind\&Yr } \\
\text { Firm }\end{array}$ & $\begin{array}{l}\text { Ind\&Yr } \\
\text { N/A }\end{array}$ & $\begin{array}{l}\text { Ind\&Yr } \\
\text { N/A }\end{array}$ & $\begin{array}{l}\text { Ind\&Yr } \\
\text { N/A }\end{array}$ & $\begin{array}{l}\text { Ind\&Yr } \\
\text { N/A }\end{array}$ \\
\hline Adjusted $\mathrm{R}^{2}$ & 0.0588 & 0.0754 & 0.0286 & 0.0706 & 0.0959 & 0.102 \\
\hline $\begin{array}{l}\text { Notes: This table presents result } \\
\text { The measurement window in co } \\
\text { average period. All variables are } \\
\text { ETR is truncated at } 0 \text { and } 1 \text {. T-s } \\
\text { reported in parentheses below th } \\
\text { and } 0.01 \text { levels, respectively usi }\end{array}$ & $\begin{array}{l}\text { stimating M } \\
\text { (ii) is a sing } \\
\text { ned in Appe } \\
\text { cs are repor } \\
\text { fficient esti } \\
\text { o-tailed test }\end{array}$ & $\begin{array}{l}1 \text { and } 2 . \mathrm{Th} \\
\text { nnual period } \\
\text { A. All conti } \\
\text { parenthese } \\
\text { The symb } \\
\text { lustry (Fame }\end{array}$ & $\begin{array}{l}\text { asurement } \\
\text { measurem } \\
\text { variables } \\
* * \text { coefficie } \\
\text { and } * *\end{array}$ & $\begin{array}{l}\text { Ww in colun } \\
\text { indow in c } \\
\text { insorized at } \\
\text { timates. Fo } \\
\text { ote statistic }\end{array}$ & $\begin{array}{l}\text { is over thre } \\
\mathrm{n} \text { (iii) is a si } \\
1 \text { and } 99 \text { per } \\
\text { joint tests, F- } \\
\text { nnificance at }\end{array}$ & $\begin{array}{l}\text { nual periods. } \\
\text {, three-year } \\
\text { levels. Cash } \\
\text { tistics are } \\
0.10,0.05\end{array}$ \\
\hline
\end{tabular}


Table 6

Effect of Large Settlements on UTB Reporting

\begin{tabular}{|c|c|c|}
\hline DEPENDENT VARIABLE $=C Y I N C \_U T B$ & Model (3) & Model (4) \\
\hline POST & $\begin{array}{c}-0.0023 \\
(-1.64)\end{array}$ & $\begin{array}{c}-0.0038^{* * *} \\
(-2.49)\end{array}$ \\
\hline UNDERRESERVED & & $\begin{array}{c}-0.0006 \\
(-0.61)\end{array}$ \\
\hline POST*UNDERRESERVED & & $\begin{array}{c}0.0030 * * \\
(2.32)\end{array}$ \\
\hline SIZE & $\begin{array}{c}-0.0004 \\
(-1.51)\end{array}$ & $\begin{array}{c}-0.0004 \\
(-1.52)\end{array}$ \\
\hline LEVERAGE & $\begin{array}{c}0.0117 * * * \\
(3.28)\end{array}$ & $\begin{array}{c}0.0112 * * * \\
\quad(3.15)\end{array}$ \\
\hline CAPX_SCALE & $\begin{array}{l}0.0020 \\
(0.26)\end{array}$ & $\begin{array}{c}0.0019 \\
(0.26)\end{array}$ \\
\hline INV_INTENSITY & $\begin{array}{c}-0.0013 \\
(-0.33)\end{array}$ & $\begin{array}{c}-0.0014 \\
(-0.37)\end{array}$ \\
\hline RD_INTENSITY & $\begin{array}{c}0.0582 * * * \\
(3.14)\end{array}$ & $\begin{array}{c}0.0539 * * * \\
(2.98)\end{array}$ \\
\hline$R O A$ & $\begin{array}{l}-0.0071 \\
(-0.87)\end{array}$ & $\begin{array}{c}-0.0041 \\
(-0.52)\end{array}$ \\
\hline FOREIGN_INCOME & $\begin{array}{c}-0.0002 \\
(-0.02)\end{array}$ & $\begin{array}{c}-0.0010 \\
(-0.13)\end{array}$ \\
\hline NOL & $\begin{array}{l}0.0008 \\
(1.01)\end{array}$ & $\begin{array}{l}0.0007 \\
(0.92)\end{array}$ \\
\hline$B I G \_N$ & $\begin{array}{c}0.0008 \\
(0.33)\end{array}$ & $\begin{array}{l}0.0001 \\
(0.05)\end{array}$ \\
\hline INTERCEPT & $\begin{array}{c}0.0073 \\
(1.65)\end{array}$ & $\begin{array}{c}0.0078^{*} \\
(1.82)\end{array}$ \\
\hline$P O S T+P O S T * U N D E R R E S E R V E D$ & & $\begin{array}{c}-0.0008 \\
(0.25)\end{array}$ \\
\hline UNDERRESERVED + POST*UNDERRESERVED & & $\begin{array}{c}0.0024 * * \\
(5.29)\end{array}$ \\
\hline $\mathrm{N}$ & 90 & 90 \\
\hline Fixed Effects & Ind\&Yr & Ind\&Yr \\
\hline Cluster & N/A & N/A \\
\hline Adjusted $\mathrm{R}^{2}$ & 0.236 & 0.286 \\
\hline
\end{tabular}

Notes: This table presents results of estimating Models 3 and 4. All variables are defined in Appendix A. All continuous variables are winsorized at the 1 and 99 percent levels. Cash ETR is truncated at 0 and 1 . T-statistics are reported in parentheses below coefficient estimates. For the joint tests, F- statistics are reported in parentheses below the coefficient estimates. The symbols *, **, and *** denote statistical significance at the $0.10,0.05$, and 0.01 levels, respectively using two-tailed tests. Industry (Fama-French 17 ) and year fixed effects are applied. 
Table 7

Effect of Large Settlements on Other Firms' Tax Avoidance in the External Auditor's Clientele

\begin{tabular}{|c|c|c|}
\hline & $\begin{array}{l}\text { Under-reserved clientele } \\
\text { (i) }\end{array}$ & $\begin{array}{c}\text { Adequately reserved } \\
\text { clientele (ii) }\end{array}$ \\
\hline DEPENDENT VARIABLE $=$ CASH_ETR & Model (1) & Model (1) \\
\hline POST & $\begin{array}{l}0.0441 * * * \\
\quad(3.05)\end{array}$ & $\begin{array}{l}0.0030 \\
(0.22)\end{array}$ \\
\hline SIZE & $\begin{array}{l}0.0006 \\
(0.16)\end{array}$ & $\begin{array}{l}0.0017 \\
(0.53)\end{array}$ \\
\hline LEVERAGE & $\begin{array}{c}-0.1529 * * * \\
(-4.40)\end{array}$ & $\begin{array}{c}-0.1156 * * * \\
(-3.14)\end{array}$ \\
\hline CAPX_SCALE & $\begin{array}{c}-0.1092 \\
(-1.07)\end{array}$ & $\begin{array}{c}-0.1975^{*} \\
(-1.70)\end{array}$ \\
\hline INV_INTENSITY & $\begin{array}{l}0.1202 * * * \\
\quad(2.68)\end{array}$ & $\begin{array}{c}0.1194 * * \\
(2.49)\end{array}$ \\
\hline RD_INTENSITY & $\begin{array}{c}-0.5371 * * * \\
\quad(-5.26)\end{array}$ & $\begin{array}{c}-0.4779 * * * \\
\quad(-3.89)\end{array}$ \\
\hline$R O A$ & $\begin{array}{l}0.2191 * * * \\
\quad(2.88)\end{array}$ & $\begin{array}{l}0.1137 \\
(1.27)\end{array}$ \\
\hline FOREIGN_INCOME & $\begin{array}{r}-0.1167 \\
(-0.94)\end{array}$ & $\begin{array}{r}0.0110 \\
(0.07)\end{array}$ \\
\hline NOL & $\begin{array}{r}-0.0035 \\
(-0.30)\end{array}$ & $\begin{array}{r}0.0027 \\
(0.24)\end{array}$ \\
\hline$B I G \_N$ & $\begin{array}{l}0.0566 * * * \\
(2.79)\end{array}$ & $\begin{array}{l}0.0212 \\
(0.79)\end{array}$ \\
\hline INTERCEPT & $\begin{array}{l}0.2967 * * * \\
\quad(4.06)\end{array}$ & $\begin{array}{l}0.2983^{* * *} \\
\quad(4.52)\end{array}$ \\
\hline $\mathrm{N}$ & 2,275 & 2,102 \\
\hline $\begin{array}{l}\text { Fixed Effects } \\
\text { Cluster }\end{array}$ & $\begin{array}{l}\text { Ind \& Yr } \\
\text { Firm }\end{array}$ & $\begin{array}{l}\text { Ind\&Yr } \\
\text { Firm }\end{array}$ \\
\hline Adjusted $\mathrm{R}^{2}$ & 0.0943 & 0.0675 \\
\hline
\end{tabular}

Notes: This table presents results of estimating Model 1 using the three-year annual specification for non-settlement firms sharing the same auditor-office as a settlement firm. Column (i) includes those clientele firms where the settlement firm had under-reserved for the large tax settlement. Column (ii) includes those clientele firms where the settlement firm had adequately reserved for the large tax settlement. All variables are defined in Appendix A. All continuous variables are winsorized at the 1 and 99 percent levels. Cash ETR is truncated at 0 and 1 . T-statistics are reported in parentheses below coefficient estimates. The symbols $*, * *$, and $* * *$ denote statistical significance at the $0.10,0.05$, and 0.01 levels, respectively using two-tailed tests. Industry (Fama-French 17) and year fixed effects are applied. 
Table 8

Effect of Large Settlements on Tax Avoidance Robustness Test

\begin{tabular}{|c|c|c|c|c|c|c|}
\hline \multirow[b]{2}{*}{$\begin{array}{l}\text { DEPENDENT } \\
\text { VARIABLE }=C A S H \_E T R\end{array}$} & \multicolumn{2}{|c|}{$\begin{array}{c}\text { 3-YR (t-4 to } t-2 \text { and } t+1 \text { to } \\
\mathrm{t}+3)(\mathrm{i})\end{array}$} & \multicolumn{2}{|c|}{$1-\mathrm{YR}(\mathrm{t}-2$ and $\mathrm{t}+1)$ (ii) } & \multicolumn{2}{|c|}{ 3-YR AVG. (iii) } \\
\hline & $\begin{array}{c}\text { Adequately } \\
\text { Reserved }\end{array}$ & $\begin{array}{l}\text { Under- } \\
\text { reserved }\end{array}$ & $\begin{array}{c}\text { Adequately } \\
\text { Reserved }\end{array}$ & $\begin{array}{l}\text { Under- } \\
\text { reserved }\end{array}$ & $\begin{array}{l}\text { Adequately } \\
\text { Reserved }\end{array}$ & $\begin{array}{l}\text { Under- } \\
\text { reserved }\end{array}$ \\
\hline POST & $\begin{array}{l}-0.0099 \\
(-0.44)\end{array}$ & $\begin{array}{l}-0.0248 \\
(-0.96)\end{array}$ & $\begin{array}{c}-0.0431 * * \\
(-2.20)\end{array}$ & $\begin{array}{l}-0.0284 \\
(-1.10)\end{array}$ & $\begin{array}{l}-0.0031 \\
(-0.08)\end{array}$ & $\begin{array}{l}-0.0488 \\
(-0.82)\end{array}$ \\
\hline LARGE_SETTLER & $\begin{array}{l}0.0036 \\
(0.22)\end{array}$ & $\begin{array}{l}0.0182 \\
(0.87)\end{array}$ & $\begin{array}{c}-0.0315^{*} \\
(-1.74)\end{array}$ & $\begin{array}{l}0.0187 \\
(0.77)\end{array}$ & $\begin{array}{l}0.0008 \\
(0.03)\end{array}$ & $\begin{array}{l}-0.0095 \\
(-0.21)\end{array}$ \\
\hline POST*LARGE_SETTLER & $\begin{array}{c}0.0220 \\
(0.95)\end{array}$ & $\begin{array}{c}0.0989 * * * \\
\quad(4.12)\end{array}$ & $\begin{array}{c}0.0569 * * \\
(2.26)\end{array}$ & $\begin{array}{l}0.1391 * * * \\
\quad(4.22)\end{array}$ & $\begin{array}{l}0.0509 \\
(1.31)\end{array}$ & $\begin{array}{l}0.1344^{* *} \\
(2.50)\end{array}$ \\
\hline SIZE & $\begin{array}{c}-0.0018 \\
(-0.39)\end{array}$ & $\begin{array}{l}-0.0052 \\
(-0.82)\end{array}$ & $\begin{array}{l}0.0033 \\
(0.76)\end{array}$ & $\begin{array}{c}-0.0119^{*} \\
(-1.91)\end{array}$ & $\begin{array}{c}-0.0022 \\
(-0.30)\end{array}$ & $\begin{array}{c}-0.0010 \\
(-0.08)\end{array}$ \\
\hline LEVERAGE & $\begin{array}{c}-0.1506 * * * \\
(-3.16)\end{array}$ & $\begin{array}{c}-0.0524 \\
(-0.83)\end{array}$ & $\begin{array}{c}-0.1016^{*} \\
(-1.91)\end{array}$ & $\begin{array}{l}0.0282 \\
(0.45)\end{array}$ & $\begin{array}{c}-0.2053 * * \\
(-2.49)\end{array}$ & $\begin{array}{l}-0.0383 \\
(-0.32)\end{array}$ \\
\hline CAPX_SCALE & $\begin{array}{l}0.0120 \\
(0.08)\end{array}$ & $\begin{array}{l}-0.0228 \\
(-0.14)\end{array}$ & $\begin{array}{l}0.1409 \\
(1.08)\end{array}$ & $\begin{array}{l}-0.1042 \\
(-0.57)\end{array}$ & $\begin{array}{l}-0.1111 \\
(-0.44)\end{array}$ & $\begin{array}{l}-0.1341 \\
(-0.37)\end{array}$ \\
\hline INV_INTENSITY & $\begin{array}{l}0.0391 \\
(1.12)\end{array}$ & $\begin{array}{l}0.0936 \\
(1.40)\end{array}$ & $\begin{array}{c}0.1287 * * \\
(2.45)\end{array}$ & $\begin{array}{l}0.0375 \\
(0.49)\end{array}$ & $\begin{array}{l}0.0403 \\
(0.51)\end{array}$ & $\begin{array}{l}0.0356 \\
(0.36)\end{array}$ \\
\hline RD_INTENSITY & $\begin{array}{c}-0.7565 * * * \\
(-3.31)\end{array}$ & $\begin{array}{c}-0.7681 * * * \\
(-2.77)\end{array}$ & $\begin{array}{c}-0.8927 * * * \\
(-3.53)\end{array}$ & $\begin{array}{c}-1.0150 * * * \\
(-2.99)\end{array}$ & $\begin{array}{r}-0.6457 \\
(-1.52)\end{array}$ & $\begin{array}{c}-0.6561 \\
(-1.62)\end{array}$ \\
\hline$R O A$ & $\begin{array}{l}0.2442 * * \\
(2.52)\end{array}$ & $\begin{array}{l}0.2705^{* *} \\
(2.15)\end{array}$ & $\begin{array}{l}0.2431 * * \\
(2.11)\end{array}$ & $\begin{array}{c}0.0275 \\
(0.15)\end{array}$ & $\begin{array}{l}0.1140 \\
(0.62)\end{array}$ & $\begin{array}{l}0.2724 \\
(1.01)\end{array}$ \\
\hline FOREIGN_INCOME & $\begin{array}{l}0.1435 \\
(0.64)\end{array}$ & $\begin{array}{l}0.2106 \\
(0.67)\end{array}$ & $\begin{array}{l}0.1597 \\
(0.70)\end{array}$ & $\begin{array}{r}0.3467 \\
(1.23)\end{array}$ & $\begin{array}{l}0.1932 \\
(0.53)\end{array}$ & $\begin{array}{c}0.5356 \\
(1.46)\end{array}$ \\
\hline$N O L$ & $\begin{array}{c}-0.0269 * * \\
(-2.10)\end{array}$ & $\begin{array}{r}-0.0129 \\
(-0.69)\end{array}$ & $\begin{array}{c}-0.0493 * * * \\
(-3.45)\end{array}$ & $\begin{array}{c}-0.0307^{*} \\
(-1.72)\end{array}$ & $\begin{array}{c}-0.0046 \\
(-0.19)\end{array}$ & $\begin{array}{c}-0.0159 \\
(-0.52)\end{array}$ \\
\hline$B I G \_N$ & $\begin{array}{c}0.0304 \\
(1.37)\end{array}$ & $\begin{array}{l}0.0445 \\
(1.36)\end{array}$ & $\begin{array}{c}-0.0421^{*} \\
(-1.91)\end{array}$ & $\begin{array}{l}0.0498 \\
(1.55)\end{array}$ & $\begin{array}{l}-0.0119 \\
(-0.31)\end{array}$ & $\begin{array}{l}0.0015 \\
(0.02)\end{array}$ \\
\hline INTERCEPT & $\begin{array}{l}0.2885 * * * \\
\quad(4.27)\end{array}$ & $\begin{array}{l}0.2508 * * * \\
\quad(3.48)\end{array}$ & $\begin{array}{l}0.2323 * * * \\
(4.19)\end{array}$ & $\begin{array}{l}0.3096^{* * * *} \\
\quad(3.57)\end{array}$ & $\begin{array}{l}0.2901 * * * \\
\quad(3.14)\end{array}$ & $\begin{array}{c}0.2798^{*} \\
(1.94)\end{array}$ \\
\hline $\begin{array}{l}P O S T+ \\
P O S T^{*} L A R G E \_S E T T L E R\end{array}$ & $\begin{array}{r}0.0121 \\
(0.31)\end{array}$ & $\begin{array}{l}0.0741 * * * \\
\quad(7.63)\end{array}$ & $\begin{array}{c}0.0138 \\
(0.46)\end{array}$ & $\begin{array}{c}0.1107 * * * \\
(18.60)\end{array}$ & $\begin{array}{c}0.0478 \\
(1.47)\end{array}$ & $\begin{array}{c}0.0856 \\
(2.05)\end{array}$ \\
\hline $\begin{array}{l}\text { LARGE_SETTLER + } \\
P O S T * L A R G E \_S E T T L E R\end{array}$ & $\begin{array}{c}0.0256 \\
(1.63)\end{array}$ & $\begin{array}{l}0.1171 * * * \\
(18.87)\end{array}$ & $\begin{array}{c}0.0254 \\
(1.97)\end{array}$ & $\begin{array}{c}0.1578 * * * \\
(43.47)\end{array}$ & $\begin{array}{c}0.0517^{*} \\
(3.21)\end{array}$ & $\begin{array}{l}0.1249 * * * \\
\quad(9.02)\end{array}$ \\
\hline $\begin{array}{l}\mathrm{N} \\
\text { Fixed Effects } \\
\text { Cluster }\end{array}$ & $\begin{array}{c}865 \\
\text { Ind\&Yr } \\
\text { Firm }\end{array}$ & $\begin{array}{c}601 \\
\text { Ind\&Yr } \\
\text { Firm }\end{array}$ & $\begin{array}{c}524 \\
\text { Ind\&Yr } \\
\text { N/A }\end{array}$ & $\begin{array}{c}360 \\
\text { Ind\&Yr } \\
\text { N/A }\end{array}$ & $\begin{array}{c}240 \\
\text { Ind\&Yr } \\
\text { N/A }\end{array}$ & $\begin{array}{c}136 \\
\text { Ind\&Yr } \\
\text { N/A }\end{array}$ \\
\hline Adjusted $\mathrm{R}^{2}$ & 0.128 & 0.175 & 0.0967 & 0.193 & 0.0210 & 0.143 \\
\hline
\end{tabular}

Notes: This table presents results of the propensity score matched sample of large settlement and non-large settlement firms. Results are reported separately for the adequately reserved sample and the under-reserved sample. The measurement window in column (i) is over three annual periods. The measurement window in column (ii) is a single, annual period. The measurement window in column (iii) is a single, three-year average period. All variables are defined in Appendix A. All continuous variables are winsorized at the 1 and 99 percent levels. Cash ETR is truncated at 0 and 1. T-statistics are reported in parentheses below coefficient estimates. For the joint tests, F- statistics are reported in parentheses below the coefficient estimates. The symbols *, **, and *** denote statistical significance at the $0.10,0.05$, and 0.01 levels, respectively using two-tailed tests. Industry (Fama-French 17) and year fixed effects are applied. 
Table 9

Effect of Large Settlements on Financial Reporting over the Tax Account

Panel A: Effect of Settlements on Subsequent UTB Reporting

DEPENDENT VARIABLE $=C Y I N C \_U T B$

Model (4) modified

\begin{tabular}{|c|c|}
\hline POST & $\begin{array}{c}-0.0017 * * * \\
(-4.74)\end{array}$ \\
\hline$L O W \_U T B \_R E T A I N$ & $\begin{array}{c}-0.0014^{* * *} \\
(-5.25)\end{array}$ \\
\hline$P O S T^{*} L O W \_U T B \_R E T A I N$ & $\begin{array}{c}0.0008 * * \\
(2.06)\end{array}$ \\
\hline SIZE & $\begin{array}{c}-0.0000 \\
(-0.09)\end{array}$ \\
\hline LEVERAGE & $\begin{array}{r}-0.0009 \\
(-1.59)\end{array}$ \\
\hline CAPX_SCALE & $\begin{array}{c}-0.0023 \\
(-0.82)\end{array}$ \\
\hline INV_INTENSITY & $\begin{array}{c}-0.0020 * * \\
(-1.99)\end{array}$ \\
\hline RD_INTENSITY & $\begin{array}{c}0.0150^{* * * *} \\
(7.39)\end{array}$ \\
\hline$R O A$ & $\begin{array}{c}0.0045^{* * * *} \\
(3.67)\end{array}$ \\
\hline FOREIGN_INCOME & $\begin{array}{c}0.0114 * * * \\
(5.35)\end{array}$ \\
\hline NOL & $\begin{array}{c}0.0003 \\
(1.37)\end{array}$ \\
\hline$B I G \_N$ & $\begin{array}{l}0.0007 \\
(1.53)\end{array}$ \\
\hline INTERCEPT & $\begin{array}{c}0.0023 * * * \\
(2.62)\end{array}$ \\
\hline$P O S T+P O S T * L O W \_U T B \_R E T A I N$ & $\begin{array}{c}-0.0009 * * \\
(5.15)\end{array}$ \\
\hline$L O W \_U T B \_R E T A I N+P O S T^{*} L O W \_U T B \_R E T A I N$ & $\begin{array}{c}-0.0006^{* * *} \\
(5.78)\end{array}$ \\
\hline $\mathrm{N}$ & 1,530 \\
\hline Fixed Effects & Ind\&Yr \\
\hline $\begin{array}{l}\text { Cluster } \\
\text { Adjusted } \mathrm{R}^{2}\end{array}$ & $\begin{array}{c}\mathrm{N} / \mathrm{A} \\
0.178 \\
\end{array}$ \\
\hline
\end{tabular}


Table 9 continued

Effect of Large Settlements on Financial Reporting over the Tax Account

Panel B: Effect of Large Settlements on Current ETR

\begin{tabular}{|c|c|c|c|c|c|c|}
\hline \multirow[b]{2}{*}{$\begin{array}{l}\text { DEPENDENT VARIABLE= } \\
\text { CURRENT_ETR }\end{array}$} & \multicolumn{2}{|c|}{$\begin{array}{l}\text { 3-Years (t-4 to } t-2 \text { and } t+1 \text { to } \\
t+3)(\mathrm{i})\end{array}$} & \multicolumn{2}{|c|}{$\begin{array}{l}1-\text { Year (t-2 and } \mathrm{t}+1) \\
\text { (ii) }\end{array}$} & \multicolumn{2}{|c|}{$\begin{array}{l}\text { 3-Year Average } \\
\text { (iii) }\end{array}$} \\
\hline & Model (1) & Model (2) & Model (1) & Model (2) & Model (1) & Model (2) \\
\hline POST & $\begin{array}{c}0.0078 \\
(0.38)\end{array}$ & $\begin{array}{l}-0.0264 \\
(-1.17)\end{array}$ & $\begin{array}{c}0.0149 \\
(0.75)\end{array}$ & $\begin{array}{l}-0.0141 \\
(-0.59)\end{array}$ & $\begin{array}{c}0.0555^{*} \\
(1.90)\end{array}$ & $\begin{array}{c}0.0220 \\
(0.70)\end{array}$ \\
\hline UNDERRESERVED & & $\begin{array}{l}-0.0064 \\
(-0.38)\end{array}$ & & $\begin{array}{r}0.0256 \\
(1.11)\end{array}$ & & $\begin{array}{l}-0.0302 \\
(-1.34)\end{array}$ \\
\hline POST *UNDERRESERVED & & $\begin{array}{c}0.0760 * * * \\
(3.73)\end{array}$ & & $\begin{array}{c}0.0667 * * \\
(2.07)\end{array}$ & & $\begin{array}{l}0.0854 * * * \\
(2.73)\end{array}$ \\
\hline SIZE & $\begin{array}{c}-0.0153 * * * \\
(-2.66)\end{array}$ & $\begin{array}{c}-0.0146 * * \\
(-2.56)\end{array}$ & $\begin{array}{c}-0.0157 * * * \\
(-2.77)\end{array}$ & $\begin{array}{c}-0.0141 * * \\
(-2.52)\end{array}$ & $\begin{array}{l}-0.0057 \\
(-1.01)\end{array}$ & $\begin{array}{l}-0.0055 \\
(-0.97)\end{array}$ \\
\hline LEVERAGE & $\begin{array}{l}-0.0649 \\
(-1.13)\end{array}$ & $\begin{array}{l}-0.0633 \\
(-1.10)\end{array}$ & $\begin{array}{l}-0.0164 \\
(-0.28)\end{array}$ & $\begin{array}{l}-0.0200 \\
(-0.34)\end{array}$ & $\begin{array}{l}-0.0731 \\
(-1.20)\end{array}$ & $\begin{array}{l}-0.0681 \\
(-1.13)\end{array}$ \\
\hline$C A P X \_S C A L E$ & $\begin{array}{c}-0.3282 * * * \\
(-2.95)\end{array}$ & $\begin{array}{c}-0.3044 * * * \\
(-2.73)\end{array}$ & $\begin{array}{c}-0.4396 * * \\
(-2.58)\end{array}$ & $\begin{array}{c}-0.3958 * * \\
(-2.35)\end{array}$ & $\begin{array}{c}-0.4554 * * \\
(-2.42)\end{array}$ & $\begin{array}{c}-0.4343 * * \\
(-2.32)\end{array}$ \\
\hline INV_INTENSITY & $\begin{array}{c}0.1106 * * \\
(2.31)\end{array}$ & $\begin{array}{c}0.1127 * * \\
(2.36)\end{array}$ & $\begin{array}{r}0.0407 \\
(0.53)\end{array}$ & $\begin{array}{c}0.0579 \\
(0.77)\end{array}$ & $\begin{array}{c}0.1152 \\
(1.64)\end{array}$ & $\begin{array}{c}0.1174 * \\
(1.69)\end{array}$ \\
\hline RD_INTENSITY & $\begin{array}{l}0.0262 \\
(0.11)\end{array}$ & $\begin{array}{l}0.0466 \\
(0.19)\end{array}$ & $\begin{array}{c}-0.2905 \\
(-1.02)\end{array}$ & $\begin{array}{c}-0.2458 \\
(-0.88)\end{array}$ & $\begin{array}{c}-0.5379 * * \\
(-2.19)\end{array}$ & $\begin{array}{c}-0.5341 * * \\
(-2.20)\end{array}$ \\
\hline$R O A$ & $\begin{array}{c}0.0766 \\
(0.49)\end{array}$ & $\begin{array}{r}0.0645 \\
(0.42)\end{array}$ & $\begin{array}{c}-0.2133 \\
(-1.41)\end{array}$ & $\begin{array}{c}-0.1856 \\
(-1.24)\end{array}$ & $\begin{array}{c}0.2539 * \\
(1.81)\end{array}$ & $\begin{array}{l}0.2155 \\
(1.54)\end{array}$ \\
\hline FOREIGN_INCOME & $\begin{array}{c}-0.3630 \\
(-1.38)\end{array}$ & $\begin{array}{c}-0.4159 \\
(-1.61)\end{array}$ & $\begin{array}{c}-0.1849 \\
(-0.67)\end{array}$ & $\begin{array}{c}-0.2702 \\
(-1.00)\end{array}$ & $\begin{array}{c}-0.0435 \\
(-0.17)\end{array}$ & $\begin{array}{c}-0.0688 \\
(-0.27)\end{array}$ \\
\hline$N O L$ & $\begin{array}{c}-0.0304 * \\
(-1.91)\end{array}$ & $\begin{array}{c}-0.0341 * * \\
(-2.15)\end{array}$ & $\begin{array}{c}-0.0188 \\
(-1.08)\end{array}$ & $\begin{array}{c}-0.0250 \\
(-1.45)\end{array}$ & $\begin{array}{c}-0.0317 * \\
(-1.75)\end{array}$ & $\begin{array}{c}-0.0349 * \\
(-1.94)\end{array}$ \\
\hline$B I G \_N$ & $\begin{array}{c}0.0478 \\
(1.51)\end{array}$ & $\begin{array}{r}0.0446 \\
(1.44)\end{array}$ & $\begin{array}{l}-0.0065 \\
(-0.23)\end{array}$ & $\begin{array}{c}-0.0100 \\
(-0.36)\end{array}$ & $\begin{array}{c}0.0549 * \\
(1.85)\end{array}$ & $\begin{array}{c}0.0538 * \\
(1.82)\end{array}$ \\
\hline INTERCEPT & $\begin{array}{c}0.3410^{* * * *} \\
(4.58)\end{array}$ & $\begin{array}{c}0.3393 * * * \\
(4.45)\end{array}$ & $\begin{array}{c}0.4590 * * * \\
(6.18)\end{array}$ & $\begin{array}{c}0.4339 * * * \\
\quad(5.82)\end{array}$ & $\begin{array}{c}0.2773 * * * \\
(3.79)\end{array}$ & $\begin{array}{c}0.2893 * * * \\
(3.92)\end{array}$ \\
\hline $\begin{array}{l}\text { POST + } \\
P O S T^{*} U N D E R R E S E R V E D\end{array}$ & & $\begin{array}{c}0.0496 * * \\
(4.76)\end{array}$ & & $\begin{array}{c}0.0526^{*} \\
(3.84)\end{array}$ & & $\begin{array}{l}0.1074 * * * \\
\quad(9.70)\end{array}$ \\
\hline $\begin{array}{l}\text { UNDERRESERVED + } \\
P O S T^{*} U N D E R R E S E R V E D\end{array}$ & & $\begin{array}{c}0.0696 * * * \\
(11.17)\end{array}$ & & $\begin{array}{c}0.0923 * * * \\
(15.95)\end{array}$ & & $\begin{array}{c}0.0552 * * \\
(6.15)\end{array}$ \\
\hline $\mathrm{N}$ & 1,250 & 1,250 & 564 & 564 & 378 & 378 \\
\hline Fixed Effects & Ind\&Yr & Ind\&Yr & Ind\&Yr & Ind\&Yr & Ind\&Yr & Ind\&Yr \\
\hline Cluster & Firm & Firm & N/A & N/A & N/A & N/A \\
\hline Adjusted R ${ }^{2}$ & 0.132 & 0.147 & 0.117 & 0.142 & 0.0778 & 0.0941 \\
\hline
\end{tabular}

Notes: Panel A presents a modification of Model (4) using the sample of firms in the highest and lowest quintiles of UTB_RETAIN with settlements disclosed in their FIN 48 tabular reconciliation. Panel B presents a modification of Models (1) and (2) using the same sample as in the main test and using current ETR as the dependent variable. The measurement window in column (i) is over three 
annual periods. The measurement window in column (ii) is a single, annual period. The measurement window in column (iii) is a

single, three-year average period. All variables are defined in Appendix A. All continuous variables are winsorized at the 1 and 99 percent levels. Current ETR is truncated at 0 and 1. T-statistics are reported in parentheses below coefficient estimates. For the joint tests, F- statistics are reported in parentheses below the coefficient estimates. The symbols *, **, and *** denote statistical

significance at the $0.10,0.05$, and 0.01 levels, respectively using two-tailed tests. Industry (Fama-French 17) and year fixed effects are applied. 


\section{REFERENCES}

Alm, J. 2012. Measuring, explaining, and controlling tax evasion: lessens from theory, experiments, and field studies. International Tax and Public Finance 19: 54-77.

Alm, J., T. Cherry, M. Jones, and M. McKee. 2010. Taxpayer information assistance services and tax compliance behavior. Journal of Economic Psychology 31: 577586.

Alm, J., B. R. Jackson, and M. McKee. 2009. Getting the word out: enforcement information dissemination and compliance behavior. Journal of Public Economics 93: 392-402.

Alm, J. and M. McKee. 2006. Audit certainty, audit productivity, and taxpayer compliance. National Tax Journal 59 (4) 801-816.

Austin, P. C. 2011. Optimal caliper widths for propensity-score matching when estimating differences in means and differences in proportions in observational studies. Pharmaceutical Statistics 10: 150-161.

Ayers, B., J. K. Seidman, E. M. Towery. 2014. Taxpayer behavior under audit certainty. Working Paper, University of Georgia and University of Texas at Austin.

Barron, G. and I. Erev. 2003. Small feedback-based decisions and their limited correspondence to description-based decisions. Journal of Behavioral Decision Making 16: 215-233.

Bauer, A. M. and K. J. Klassen. 2014. Estimating downside tax risk using large unfavorable tax payments. Working Paper, University of Illinois at UrbanaChampaign, University of Waterloo.

Bianci, P. A., D. Falsetta, Minutti-Meza, M., and E. Weisbrod. 2014. Auditors' professional networks and tax avoidance: evidence from private firms. Working Paper, University of Miami.

Blouin, J. L. and L. A. Robinson. 2014. Insights from academic participation in the FAF's initial PIR: the PIR of FIN 48. Accounting Horizons 28 (3): 479-500.

Bozanic, Z., J. L. Hoopes, J. R. Thornock, B. M. Williams. 2014. IRS Attention. Working Paper, Ohio State University, University of Washington.

Brown, J. L. and K. D. Drake. 2014. Network ties among low-tax firms. The Accounting Review 89 (2): 483-510. 
Cheng, M., D. Dhaliwal, and Y Zhang. 2013. Does investment efficiency improve after the disclosure of material weaknesses in internal control over financial reporting. Journal of Accounting and Economics 56 (1): 1-18.

DeBacker, J., B. T. Heim, A. Tran, and A. Yuskavage. 2013. Legal enforcement and corporate behavior: an analysis of tax aggressiveness after an audit. Working paper, Middle Tennessee State University, Indiana University, U.S. Department of Treasury

De Simone, L., J. R. Robinson, and B. Stomberg. 2014. Distilling the reserve for uncertain tax positions: the revealing case of black liquor. Review of Accounting Studies 19: 456-472.

Dittmar, A. and R. Duchin. 2014. Looking in the rear view mirror: the effect of managers' professional experience on corporate financial policy. Working Paper, University of Michigan.

Drake, K., A. Finley, and A. Koester. 2014. Determinants and implications of uncertain tax position resolution. Working Paper, University of Arizona and Georgetown University.

Dubin, J. 2007. Criminal investigation enforcement activities and taxpayer noncompliance. Public Finance Review 35 (4): 500-529.

Dyreng, S. D., M. Hanlon, and E. L. Maydew. 2008. Long-run corporate tax avoidance. The Accounting Review 83 (1): 61-82.

Edwards, A., C. Schwab, and T. Shevlin. 2014. Financial constraints and cash tax savings. Working Paper, University of Toronto, University of Georgia, University of California Irvine.

Erard, Brian. 1992. The influence of tax audits on reporting behavior. In Slemrod, Joel (ed.), Why People Pay Taxes: Tax Compliance and Enforcement: 95-114. University of Michigan Press, Ann Arbor, MI.

Financial Accounting Standards Board (FASB). 2006. FASB Interpretation No. 48, Accounting for uncertainty in income taxes, an interpretation of FASB Statement No. 109. Norwalk, CT: FASB.

-2009. Accounting Standards Codification Topic 740 Income Taxes. Norwalk, CT: FASB. 1975. Statement of Financial Accounting Standards (SFAS) No. 5, Accounting for Contingencies, Norwalk, CT: FASB.

Frank, M. M., L. J. Lynch, and S. O. Rego. 2009. Tax reporting aggressiveness and its relation to aggressive financial reporting. The Accounting Review (84) 2: 467-496. 
Gemmell, N. and M. Ratto. 2012. Behavioral responses to taxpayer audits: evidence from random taxpayer inquiries. National Tax Journal 65 (1): 33-58.

Gleason, C. A. and Mills, L. F. 2002. Materiality and contingent tax liability reporting. The Accounting Review 77 (2): 317-342.

Gleason, C. A. and Mills, L. F. 2011. Do auditor-provided tax services improve the estimate of tax reserves? Contemporary Accounting Research 28 (5): 1484-1509

Graham, J. R., M. Hanlon, T. Shevlin, and N. Shroff. 2014. Incentives for tax planning and avoidance: evidence from the tield. The Accounting Review, forthcoming.

Gupta, S., R. Laux, and D. Lynch. 2013. Do firms use tax reserves to meet analysts' forecasts? Evidence from the pre and post-FIN 48 periods, Working Paper, Michigan State University and Pennsylvania State University.

Hertwig, R., G. Barron, E. U. Weber, and I. Erev. 2004. Decisions from experience and the effect of rare events in risky choice. Psychological Science 15 (8): 534-539.

Hoopes, J. L., D. Mescall, and J. A. Pittman. 2012. Do IRS audits deter corporate tax avoidance? The Accounting Review 87 (5): 1603-1639.

Internal Revenue Service (IRS). 2012. Tax Gap for Tax Year 2006. Available at: http://www.irs.gov/pub/newsroom/overview_tax_gap_2006.pdf.

Internal Revenue Service (IRS). 2012. Data Book. Available at: http://www.irs.gov/pub/irs-soi/12databk.pdf.

Karpoff, J. M., D. S. Lee, and G. S. Martin. 2008. The consequences to managers for financial misrepresentation. Journal of Financial Economics 88: 193-215.

Kedia, S. and S. Rajgopal. 2011. Do the SEC's enforcement preferences affect corporate misconduct? Journal of Accounting and Economics 51: 259-278.

Lennox, C. and B. Li. 2014. Accounting misstatements following lawsuits against auditors. Journal of Accounting and Economics 57: 58-75.

Levitt, S. D. and J. A. List. 2007. What do laboratory experiments measuring social preferences reveal about the real world? Journal of Economic Perspectives 21 (2): 153-174.

Lisowsky, P., L. Robinson, and A. Schmidt. 2013. Do publicly disclosed tax reserves tell us about privately disclosed tax shelter activity? Journal of Accounting Research 51 (3): 583-629. 
Long, S. B. and R. D. Schwartz. 1987. The impact of IRS audits on taxpayer compliance: A field experiment in specific deterrence. Paper presented at the Annual Meeting of the Law and Society Asscociation, Washington D.C.

Malmendier, U. and S. Nagel. 2011. Depression babies: do macroeconomic experiences affect risk taking? The Quarterly Journal of Economics 126: 373-416.

Mills and Sansing. 2000. Strategic Tax and Financial Reporting Decisions: Theory and Evidence. Contemporary Accounting Research 17 (1): 85-106.

McGuire, S. T., T. C. Omer, and D. Wang. 2012. Tax avoidance: does tax-specific industry expertise make a difference? The Accounting Review 87 (3): 975-1003.

McNichols, M. F. and S. R. Stubben. 2008. Does earnings management affect firms' investment decisions? The Accounting Review 83 (6): 1571-1603.

Office of Management and Budget (OMB), 2014. Historical Tables, Table 2.1 Available at:

http://www.whitehouse.gov/omb/budget/Historicals/.

Plumley, A. H. 1996. The determinants of individual income tax compliance. Internal Revenue Service Publication 1916 (Rev. 11-96). Internal Revenue Service, U.S. Department of Treasury, Washington D.C.

Reed, K. 2006. "GSK pays 'biggest tax settlement in U.S. history."' Accountancy Age, September 9, 2006.

Rego, S. O. and R. Wilson. 2012. Equity risk incentives and corporate tax aggressiveness. Journal of Accounting Research 50 (3): 775-810.

Robinson, L., B. Stomberg, and E. Towery. 2014. One size does not fit all: the effect of guidance intended to improve comparability on relevance. Working Paper, Dartmouth University, University of Georgia.

Saavedra, D. 2014. Risky high effective tax rate firms, Working Paper, Massachusetts Institute of Technology.

Shimshack J. P., and M. B. Ward. 2008. Enforcement and over-compliance. Journal of Environmental Economics and Management 55: 90-105.

Slemrod, J. 2004. The economics of corporate selfishness. National Tax Journal 57(4): 877-899.

Slemrod, J. 2007. Cheating ourselves: The economics of tax evasion. Journal of Economic Perspectives 21: 25-48. 
Slemrod, J., M. Blumenthal, and C. Christian. 2001. Taxpayer response to an increased probability of audit: evidence from a controlled experiment in Minnesota. Journal of Public Economics 79: 455-483.

Snow, A. and R. S. Warren, Jr. 2007. Audit uncertainty, bayesian updating, and tax evasion. Public Finance Review 35: 555-571.

Tauchen, H. V., A. D. Witte, and K. J. Beron. 1993. Tax compliance: an investigation using individual TCMP data." Journal of Quantitative Criminology 9 (2): 177-202.

Wiedman, C. I. and K. B. Hendricks. 2013. Firm accrual quality following restatements: a signalling view. Journal of Business Finance \& Accounting 40 (9): 1095-1125. 